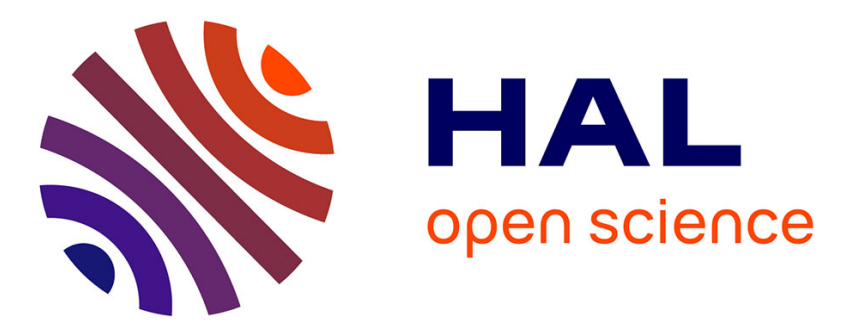

\title{
Prediction of photophysical properties of pyrimidine chromophores using Taguchi method
}

Charline Denneval, Sylvain Achelle, Christine Baudequin, Françoise Robin-Le

\section{To cite this version:}

Charline Denneval, Sylvain Achelle, Christine Baudequin, Françoise Robin-Le. Prediction of photophysical properties of pyrimidine chromophores using Taguchi method. Dyes and Pigments, 2014, 110, pp.49-55. 10.1016/j.dyepig.2014.05.030 . hal-01072193

\section{HAL Id: hal-01072193 \\ https://hal.science/hal-01072193}

Submitted on 7 Oct 2014

HAL is a multi-disciplinary open access archive for the deposit and dissemination of scientific research documents, whether they are published or not. The documents may come from teaching and research institutions in France or abroad, or from public or private research centers.
L'archive ouverte pluridisciplinaire HAL, est destinée au dépôt et à la diffusion de documents scientifiques de niveau recherche, publiés ou non, émanant des établissements d'enseignement et de recherche français ou étrangers, des laboratoires publics ou privés. 


\section{Prediction of photophysical properties of pyrimidine chromophores using Taguchi method.}

Charline Denneval, ${ }^{1}$ Sylvain Achelle, ${ }^{2 *}$ Christine Baudequin, ${ }^{1}$ and Françoise Robin-le Guen. ${ }^{2}$

${ }^{1}$ Normandie Univ. COBRA, UMR 6014 et FR 3038; Univ. Rouen; INSA Rouen; CNRS, IRCOF, 1 rue Tesnière, 76821 Mont Saint Aignan Cedex, France

${ }^{2}$ Institut des Sciences Chimiques de Rennes UMR CNRS 6226, IUT de Lannion, rue Edouard Branly, BP 30219, F22302 Lannion Cedex, France

Corresponding author: sylvain.achelle@univ-rennes1.fr Tel: +33 (0)2 96469448 Fax : + 33

(0)296469354. 


\begin{abstract}
This paper presents the photophysical properties of a series of pyrimidine chromophores. The influence of three parameters has been studied: the nature of the electron-donating group and of the $\pi$-conjugated linker as well as the substituted position of the pyrimidine core $(2,4$ and 6 position). Taguchi design of experiment combined with analysis of variance methodologies have been employed. This approach has permitted to highlight the main factor affecting the absorption and emission wavelengths of the studied compounds. Absorption maxima of this family of compounds can be predicted with relatively good precision $( \pm 18 \mathrm{~nm})$. The emission maxima can be also predicted, however the precision is lower $( \pm 39 \mathrm{~nm})$. Taguchi methodology has been also employed with these families of compounds to optimize the intramolecular charge transfer estimated by emission solvatochromy.
\end{abstract}

Key words: Pyrimidine, Photophysical Properties, Intramolecular Charge Transfer, Design of Experiment, Dyes

\title{
1. Introduction
}

Donor-acceptor $\pi$-conjugated (D- $\pi$-A) materials, also called push-pull materials, with both electron-donating and electron-withdrawing groups linked by a $\pi$-conjugated bridge have been extensively studied during the past decades [1]. In such molecules, Intramolecular Charge Transfer (ICT) that occurs can be easily illustrated by two limiting resonance forms (aromatic and quinoid/zwitterionic arrangements) [2]. Push-pull structures have found useful applications in fluorescent dyes and sensors [3], sensitizers for Dye-Sensitized Solar-Cells (DSSCs) [4] and emitters for Organic Light-Emitting Diodes (OLED) [5]. This molecular design is also typical of second and third order Non-Linear Optical (NLO) chromophores [6]. Second order NLO materials have found applications in green laser obtained from red sources through frequency doubling, in second-harmonic generation microscopy or in terahertz wave 
generation [7]. Third order NLO, in particular two-photon absorption (TPA) materials have also attracted considerable attention due to their applications in photodynamic therapy, confocal microscopy, optical power limiting, 3D data storage and microfabrication [8]. In case of second order NLOphores, the NLO answer $(\mu \beta)$ is directly related to the intensity of the ICT phenomena [9].

Pyrimidine, which is a highly $\pi$-deficient heterocycle, can be used as electron-withdrawing part in push-pull structure. The ability of protonation, hydrogen bond formation and chelation of the nitrogen atoms of the pyrimidine ring are also of great importance: such derivatives could be therefore used for the formation of supramolecular assemblies and as sensors. The use of pyrimidine ring in the structure of $\pi$-conjugated materials has been recently reviewed [10]. During the past decade, hundreds of pyrimidine chromophores have been designed. In particular numerous arylpyrimidine derivatives have been studied as fluorescent dyes [11]. Moreover, it should be noted that 4,6-di(arylvinyl)pyrimidine is now a well established structure of TPA dyes [12]. Recently, the second order NLO properties of 4arylvinylpyrimidine have been also studied [13].

Even if the solvent polarity affects the absorption spectra of push-pull compounds [14], the emission solvatochromism is generally more intense. Broad structureless red shifted emission is observed on increasing the solvent polarity along with a successive decrease in the fluorescence intensity. This solvatochromic behavior results from the stabilization of the highly polar emitting state by polar solvents [15]. Therefore studying the emission solvatochromism is a way to evaluate ICT upon excitation in push-pull structures. Different scales have been described for quantification of solvent polarity [16], one of them is the Dimroth-Reichardt $\left(\mathrm{E}_{\mathrm{T}}(30)\right)$ polarity scale based on the solvatochromic method [17]. Taguchi robust design method is a combination of mathematical and statistical techniques used in an empirical study [18]. The Taguchi design of experiment method has become a 
standard method to enhance the quality of products and processes. In principle, the Taguchi's design of experiments is used to get information such as main effects and interaction effects of design parameters from minimum number of experiments. It consists in an experimental strategy in which the effects of multiple factors are studied simultaneously by running tests with the core factors at various levels. In the Taguchi approach, experiments are designed using special orthogonal arrays that allow the parameter space to be examined by performing a limited number of experiments. It is therefore economical for characterizing a complicated process. Fewer experiments are required to study all levels of all input parameters, and filters out some effects due to statistical variation. Taguchi design of experiments method has been widely used in chemistry for the optimization of synthetic procedure [19]. However, only few examples of statistical studies dedicated to the photophysical data of series of dyes have been described. Bureš and coworkers used statistical treatment to rationalize the photophysical data of a series of heterocyclic compounds [20], and more recently, Chen et al described the optimization of luminescence properties of materials by design of experiments methodologies

The aim of the work described in this paper is to predict the absorption and emission maxima and to optimize ICT, estimated by the importance of emission solvatochromism, of a series of pyrimidine chromophores (Figure 1). The influence of three parameters has been studied: the nature of the electron-donating group and of the $\pi$-conjugated linker as well as the substituted position of the pyrimidine core (2, 4 and 6 position).

\section{$<$ Figure1 $>$}

\section{Materials and method}

\section{1. method}

In order to predict the absorption and emission maxima and to optimize ICT in pyrimidine chromophores, three parameters have been studied: the nature of the electron-donating group, 
the nature of the $\pi$-conjugated linker and the substituted position of the pyrimidine core. For each parameter, three levels have been considered (Table 1). The orthogonal array of $\mathrm{L}_{9}$ type was used and is represented in Table 2, where column D is used as control to check if there are interactions between factors A-C. The corresponding compounds are represented in Figure 2. It should be noted that in case of compound $\mathbf{3}$, for solubility reasons, the methoxy groups have been replaced by hexyloxy group. This modification is supposed to have a negligible influence on the photophysical parameters studied.

$<$ Table 1>

$<$ Table 2>

$<$ Figure 2 $>$

\subsection{General experimental}

All solvents were reagent grade. The starting materials were purchased from Sigma-Aldrich or Acros and used without further purification. For air and moisture-sensitive reactions, all glassware pieces were flame-dried and cooled under nitrogen. NMR spectra were recorded in $\mathrm{CDCl}_{3}$, on a Bruker Advance 300 spectrometer $\left({ }^{1} \mathrm{H}\right.$ at $300 \mathrm{MHz}$ and ${ }^{13} \mathrm{C}$ at $\left.75 \mathrm{MHz}\right)$. The chemical shifts $\delta$ are reported in ppm relative to the residual solvent $\left(\mathrm{CHCl}_{3}\right)$. The coupling constants $J$ are given in Hz. In the ${ }^{1} \mathrm{H}$ NMR spectra, the following abbreviations are used to describe the peak patterns: s (singlet), d (doublet), dd (doublet of doublet), $t$ (triplet), $m$ (multiplet). In the ${ }^{13} \mathrm{C}$ NMR spectra, the nature of the carbons $\left(\mathrm{C}, \mathrm{CH}, \mathrm{CH}_{2}\right.$ or $\mathrm{CH}_{3}$ ) was determined by performing a JMOD experiment. Melting points $\left({ }^{\circ} \mathrm{C}\right)$ were measured on a Kofler hot-stage with a precision of 2 degrees $\left( \pm 2^{\circ} \mathrm{C}\right)$. High-resolution mass analyses were performed at the "Centre Régional de Mesures Physiques de l'Ouest" (CRMPO, University of Rennes1) using a Bruker MicroTOF-Q II apparatus. Analytical thin layer chromatographies (TLC) were performed on silica gel plates (Merck 60F254) and compounds were visualized 
by irradiation with UV light at 254 and $365 \mathrm{~nm}$. Flash chromatography was performed using silica Acros SI 60 (60-200 mesh ASTM). UV-Visible spectra were recorded on a Varian Cary 50 scan spectrophotometer. Fluorescence spectroscopy studies were conducted on a Varian Cary Eclipse spectrophotometer. Compounds were excited at their absorption maxima (band of lowest energy) for recording the emission spectra. All solutions were measured with optical densities below 0.1 . Fluorescence quantum yield $( \pm 10 \%)$ determined relative to quinine sulfate in $1 \mathrm{M} \mathrm{H}_{2} \mathrm{SO}_{4}\left(\Phi_{\mathrm{F}}=0.54\right)$ or harmane in $0.1 \mathrm{M} \mathrm{H}_{2} \mathrm{SO}_{4}$ as standard $\left(\Phi_{\mathrm{F}}=0.83\right)$. Stokes shifts were calculated considering the lowest energetic absorption band.

\subsection{Synthesis}

Compounds 1 [22], 2 [23], 3 [24], 5 [13a], 6 [11a], 9 [22] have been synthesized according to reported methods. The synthetic routes to chromophores $4,7,8$ and 12 are reported in schemes 1-4.

\section{$<$ Scheme 1 $>$ \\ $<$ Scheme 2> \\ $<$ Scheme 3> \\ $<$ Scheme 4>}

\subsection{General Knoevenagel condensation procedure}

A stirred mixture of methylpyrimidine derivative $(1.5 \mathrm{mmol})$ and corresponding aldehyde (1.5 mmol) in aqueous sodium hydroxide $(5 \mathrm{M}, 15 \mathrm{~mL})$ containing Aliquat $336(64 \mathrm{mg}, 0.15$ mmol) was heated under reflux for $3 \mathrm{~h}$. The mixture was allowed to cool, the precipitate was filtered off, and washed with water.

\subsection{Synthesis of 4}

Compound 4 was synthesized according to general Knoevenagel condensation procedure and the crude product was purified by column chromatography $\left(\mathrm{SiO}_{2}, \mathrm{AcOEt} / \mathrm{Petroleum}\right.$ Ether, 
1:1); yellow solid; $216 \mathrm{mg}$; yield $64 \%$; $\mathrm{mp}: 149-152^{\circ} \mathrm{C} ;{ }^{1} \mathrm{H}$ NMR $\left(300 \mathrm{MHz}, \mathrm{CDCl}_{3}\right) \delta 3.01$ (s, 6H), $6.71(\mathrm{~d}, 1 \mathrm{H}, J=9.0 \mathrm{~Hz}), 7.01(\mathrm{t}, 1 \mathrm{H}, J=4.8 \mathrm{~Hz}), 7.03(\mathrm{~d}, 1 \mathrm{H}, J=16.2 \mathrm{~Hz}), 7.53(\mathrm{~d}$, $2 \mathrm{H}, J=9.0 \mathrm{~Hz}), 7.92(\mathrm{~d}, 1 \mathrm{H}, J=16.2 \mathrm{~Hz}), 8.65(\mathrm{~d}, 2 \mathrm{H}, J=4.8 \mathrm{~Hz}) ;{ }^{13} \mathrm{C}$ NMR and JMOD $(75$ $\left.\mathrm{MHz}, \mathrm{CDCl}_{3}\right) \delta 165.7(\mathrm{C}), 156.9(\mathrm{CH}), 151.1(\mathrm{C}), 138.5(\mathrm{CH}), 129.1(\mathrm{C}), 124.1(\mathrm{C}), 122.5$

$(\mathrm{CH}), 117.6(\mathrm{CH}), 112.1(\mathrm{CH}), 40.2\left(\mathrm{CH}_{3}\right)$; Anal. Calcd for $\mathrm{C}_{14} \mathrm{H}_{15} \mathrm{~N}_{3}: \mathrm{C}, 74.64 ; \mathrm{H}, 6.71 ; \mathrm{N}$, 18.65. Found C, 74.51; H, 6.95; N, 18.37.

\subsection{Synthesis of $\mathbf{1 0}$}

Compound 10 was synthesized according to general Knoevenagel condensation procedure and the crude product was purified by column chromatography $\left(\mathrm{SiO}_{2}, \mathrm{AcOEt} / \mathrm{Petroleum}\right.$ Ether, 1:1); cream solid; $172 \mathrm{mg}$; yield 44\%; ${ }^{1} \mathrm{H}$ NMR $\left(300 \mathrm{MHz}, \mathrm{CDCl}_{3}\right) \delta 7.12(\mathrm{t}, 1 \mathrm{H}, J=$ $4.8 \mathrm{~Hz}), 7.22(\mathrm{~d}, 1 \mathrm{H}, J=16.2 \mathrm{~Hz}), 7.48(\mathrm{~d}, 1 \mathrm{H}, J=8.7 \mathrm{~Hz}), 7.52(\mathrm{~d}, 2 \mathrm{H}, J=8.7 \mathrm{~Hz}), 7.91(\mathrm{~d}$, $1 \mathrm{H}, J=16.2 \mathrm{~Hz}), 8.72(\mathrm{~d}, 2 \mathrm{H}, J=4.8 \mathrm{~Hz}) ;{ }^{13} \mathrm{C} \mathrm{NMR}$ and JMOD $\left(75 \mathrm{MHz}, \mathrm{CDCl}_{3}\right) \delta 164.7$ (C), $157.1(\mathrm{CH}), 136.8(\mathrm{CH}), 134.9(\mathrm{C}), 132.0(\mathrm{CH}), 129.0(\mathrm{CH}), 128.1(\mathrm{CH}), 123.1(\mathrm{C})$, 118.7 (CH); Anal. Calcd for $\mathrm{C}_{12} \mathrm{H}_{9} \mathrm{BrN}_{2}: \mathrm{C}, 55.20 ; \mathrm{H}, 3.47 ; \mathrm{N}, 10.73$. Found C, 55.15; H, $3.56 ; \mathrm{N}, 10.57$.

\subsection{General Suzuki cross-coupling reaction procedure}

A stirred mixture of halogeno derivative $(1 \mathrm{mmol})$, corresponding phenylboronic acid (1.2 mmol), $\mathrm{Pd}\left(\mathrm{PPh}_{3}\right)_{4}(58 \mathrm{mg}, 0.05 \mathrm{mmol})$, aqueous $1 \mathrm{M}$ sodium carbonate $(1 \mathrm{mmol}, 1 \mathrm{~mL})$ and ethanol $(1 \mathrm{~mL})$ in degassed toluene $(10 \mathrm{~mL})$ was heated under nitrogen for $24 \mathrm{~h}(40 \mathrm{~h}$ in case of 12). The reaction mixture was cooled, filtered, and dissolved with a mixture of EtOAc and water 1:1 $(50 \mathrm{~mL})$ and the organic layer separated. The aqueous layer was extracted with EtOAc $(2 \times 25 \mathrm{~mL})$. The combined organic extracts were dried with $\mathrm{MgSO}_{4}$ and the solvents evaporated.

\subsection{Synthesis of 7}


Compound 7 was synthesized according to general Suzuki cross coupling reaction procedure and the crude product was purified by column chromatography $\left(\mathrm{SiO}_{2}, \mathrm{AcOEt} / \mathrm{Petroleum}\right.$ Ether, 1:1); yellow solid; $296 \mathrm{mg}$; yield $70 \%$; mp : 182-186 ${ }^{\circ} \mathrm{C} ;{ }^{1} \mathrm{H} \mathrm{NMR}\left(300 \mathrm{MHz}, \mathrm{CDCl}_{3}\right) \delta$ 7.10-7.03 (m, 3H), 7.16-7.12 (m, 7H), 7.31-7.28 (m, 4H), $7.52(\mathrm{~d}, 2 \mathrm{H}, J=8.7 \mathrm{~Hz}), 7.62(\mathrm{~d}$, $2 \mathrm{H}, J=8.4 \mathrm{~Hz}), 7.69(\mathrm{~d}, 2 \mathrm{H}, J=8.4 \mathrm{~Hz}), 8.03(\mathrm{~d}, 1 \mathrm{H}, J=16.2 \mathrm{~Hz}), 8.74(\mathrm{~d}, 2 \mathrm{H}, J=4.8 \mathrm{~Hz})$; ${ }^{13} \mathrm{C}$ NMR and JMOD (75 MHz, $\left.\mathrm{CDCl}_{3}\right) \delta 165.0(\mathrm{C}), 157.1(\mathrm{CH}), 147.6(\mathrm{C}), 147.5(\mathrm{C}), 141.3$ (C), $137.8(\mathrm{CH}), 134.5(\mathrm{C}), 134.1(\mathrm{C}), 129.3(\mathrm{CH}), 128.2(\mathrm{CH}), 127.6(\mathrm{CH}), 127.0(\mathrm{CH})$, $126.9(\mathrm{CH}), 124.6(\mathrm{CH}), 123.7(\mathrm{CH}), 123.1(\mathrm{CH}), 118.4(\mathrm{CH})$; HRMS (ESI+, ASAP) m/z calculated for $\mathrm{C}_{30} \mathrm{H}_{24} \mathrm{~N}_{3}[\mathrm{M}+\mathrm{H}]^{+} 426.1970$, found 426.1968 .

\subsection{Synthesis of 11}

Compound 11 was synthesized according to general Suzuki Cross coupling reaction procedure and the crude product was purified by column chromatography $\left(\mathrm{SiO}_{2}\right.$, AcOEt/Petroleum Ether, 1:9); pale yellow solid; $250 \mathrm{mg}$; yield $70 \%$; mp : $147-149^{\circ} \mathrm{C} ;{ }^{1} \mathrm{H}$ NMR (300 MHz, $\left.\mathrm{CDCl}_{3}\right) \delta$ 7.20-7.10 (m, 8H), 7.37-7.31 (m, 4H), 7.65 (s, 1H), 7.94 (d, 2H, $J$ $=8.7 \mathrm{~Hz}), 8.96(\mathrm{~s}, 1 \mathrm{H}) ;{ }^{13} \mathrm{C}$ NMR and JMOD $\left(75 \mathrm{MHz}, \mathrm{CDCl}_{3}\right) \delta 165.1(\mathrm{C}), 161.5(\mathrm{C}), 158.9$ $(\mathrm{CH}), 151.3(\mathrm{C}), 146.7(\mathrm{C}), 129.7(\mathrm{CH}), 128.4(\mathrm{CH}), 127.5(\mathrm{C}), 125.7(\mathrm{CH}), 124.4(\mathrm{CH})$, $121.3(\mathrm{CH}), 115.8(\mathrm{CH})$; HRMS $\left(\mathrm{ESI}^{+}\right.$, ASAP) $\mathrm{m} / \mathrm{z}$ calculated for $\mathrm{C}_{22} \mathrm{H}_{17} \mathrm{ClN}_{3}[\mathrm{M}+\mathrm{H}]^{+}$ 358.1106, found 358.1109.

\subsection{Synthesis of $\mathbf{8}$}

To a stirred mixture of compound $\mathbf{1 1}(150 \mathrm{mg}, 0.42 \mathrm{mmol})$, sodium hydrogenocarbonate (43 mg, $0.50 \mathrm{mmol})$ and Pd-C (5 mg, $0.04 \mathrm{mmol})$ in EtOH $(5 \mathrm{~mL})$, dihydrogen was introduced in bubbles at $\mathrm{rt}$ for $20 \mathrm{~h}$. The mixture was then filtered with celite and the solvent removed. The crude product was purified by column chromatography $\left(\mathrm{SiO}_{2}\right.$, AcOEt/Petroleum Ether, 1:4); yellow solid; $124 \mathrm{mg}$; yield 92\%; mp : 104-107 ${ }^{\circ} \mathrm{C}$; ${ }^{1} \mathrm{H}$ NMR 
$\left(300 \mathrm{MHz}, \mathrm{CDCl}_{3}\right) \delta$ 7.08-7.17 (m, 8H), 7.25-7.33 (m, 4H), $7.61(\mathrm{~d}, J=5 \mathrm{~Hz}, 1 \mathrm{H}), 7.95(\mathrm{~d}$, $J=8.7 \mathrm{~Hz}, 2 \mathrm{H}), 8.67(\mathrm{~d}, J=5 \mathrm{~Hz}, 1 \mathrm{H}), 9.19(\mathrm{~s}, 1 \mathrm{H}) ;{ }^{13} \mathrm{C}$ NMR and JMOD $\left(75 \mathrm{MHz}, \mathrm{CDCl}_{3}\right)$ $\delta 163.3(\mathrm{C}), 158.9(\mathrm{CH}), 157.0(\mathrm{C}), 150.7(\mathrm{CH}), 146.9(\mathrm{CH}), 129.5(\mathrm{CH}), 128.9(\mathrm{C}), 128.1(\mathrm{CH})$, $125.4(\mathrm{CH}), 124.0(\mathrm{CH}), 121.7(\mathrm{CH}), 116.1(\mathrm{C}) ; \mathrm{HRMS}\left(\mathrm{ESI}^{+}, \mathrm{ASAP}\right) \mathrm{m} / \mathrm{z}$ calculated for $\mathrm{C}_{22} \mathrm{H}_{17} \mathrm{~N}_{3}[\mathrm{M}+\mathrm{H}]^{+}$324.1501, found 324.1511

\subsection{Synthesis of $\mathbf{1 2}$}

Compound 12 was synthesized according to general Suzuki Cross coupling reaction procedure and the crude product was purified by crystallization from of mixture of $\mathrm{DCM} /$ pentane; orange solid; $261 \mathrm{mg}$; yield $34 \%$; mp : $125-130{ }^{\circ} \mathrm{C} ;{ }^{1} \mathrm{H} \mathrm{NMR}(300 \mathrm{MHz}$, $\left.\mathrm{CDCl}_{3}\right) \delta$ 7.03-7. $05(\mathrm{~m}, 6 \mathrm{H}), 7.12-7.16(\mathrm{~m}, 12 \mathrm{H}), 7.26-7.32(\mathrm{~m}, 9 \mathrm{H}), 7.51(\mathrm{~d}, J=8.7 \mathrm{~Hz}, 4 \mathrm{H})$, $8.13(\mathrm{~d}, J=8.7 \mathrm{~Hz}, 4 \mathrm{H}), 8.15(\mathrm{~d}, J=8.7 \mathrm{~Hz}, 4 \mathrm{H}), 7.95(\mathrm{~d}, J=15.9 \mathrm{~Hz}, 2 \mathrm{H}), 9.12(\mathrm{~s}, 1 \mathrm{H}) ;{ }^{13} \mathrm{C}$ NMR and JMOD (75 MHz, $\left.\mathrm{CDCl}_{3}\right) \delta 162.9(\mathrm{C}), 158.8(\mathrm{C}), 147.8(\mathrm{C}), 147.6(\mathrm{C}), 141.7(\mathrm{CH})$, $136.8(\mathrm{CH}), 134.1(\mathrm{C}), 133.8(\mathrm{C}), 129.5(\mathrm{CH}), 128.3(\mathrm{CH}), 127.7(\mathrm{CH}), 127.0(\mathrm{CH}), 125.5$ $(\mathrm{CH}), 124.7(\mathrm{CH}), 123.7(\mathrm{CH}), 123.3(\mathrm{CH}), 116.6(\mathrm{CH}) ; \mathrm{HRMS}\left(\mathrm{ESI}^{+}, \mathrm{ASAP}\right) \mathrm{m} / \mathrm{z}$ calculated for $\mathrm{C}_{56} \mathrm{H}_{42} \mathrm{~N}_{4}[\mathrm{M}+\mathrm{H}]^{+}$771.3480, found 771.3488.

\section{Results and discussion}

The UV-Vis and photoluminescence (PL) spectroscopic data of compounds 1-9 measured in dichloromethane at $25^{\circ} \mathrm{C}$ are presented in table 3 . Analyses have been carried out using low concentration solutions in order to avoid self-absorption effect. As an example, the spectra for derivative 9 are shown in Figure 3. All compounds are photostable during photophysical experiments.

$<$ Table 3>

$<$ Figure 3 $>$ 
The absorption and emission maxima have been studied according to Taguchi methodology and analysis of variance (ANOVA) was conducted to determine the significance of each factor. For absorption, the effects of each level of each factor are presented in Table 4 and the results of ANOVA calculations are given in Table 5. The average absorption wavelength is $367 \mathrm{~nm}$. As shown in Table 4, the diphenylamino group (level 3 of factor A) is the substituent leading to the most red-shifted absorption. 2-substituted pyrimidine (level 1, factor B) are the most blue shifted whereas 4,6-disubstituted derivatives (level 3, factor B) are the most red shifted. Concerning the $\pi$-conjugated core, phenylenevinylene derivatives (level 2, factor C) are the most red shifted.

Similar tables for emission are given in supporting information, the average emission wavelength is $476 \mathrm{~nm}$. It should be noted that the substitution position of the pyrimidine core affect differently the absorption and the emission: 4-monosubstituted derivatives (level 2, factor B) are more red shifted in emission than 4,6-disubstituted pyrimidines (level 3, factor B).

Either for $\lambda_{\mathrm{abs}}$ and $\lambda_{\mathrm{em}}$, the influence of residue is low (below 3.3\%) indicating that there is no interaction between the three factors studied. The F-ratio test was conducted to evaluate the effect of each factor on the signal/noise ratio. For absorption, the three factors $\mathrm{A}, \mathrm{B}$ and $\mathrm{C}$ have F-ratios superior to the F-value for a $90 \%$ confidence level $\left(\mathrm{F}-\right.$-value $\left._{0.9}=9\right)$ making them significant. For emission, only factors $\mathrm{A}$ and $\mathrm{C}$ are significant. As shown in table 4, the nature of the electron-donating group (factor A, 48.0\%) and the substituted position of the pyrimidine ring (factor B, 28.4\%) are the main factor influencing the absorption wavelength. The emission wavelength mainly depends on the nature of the $\pi$-conjugated core (factor $\mathrm{C}$, $45.3 \%$ ) and of the electron-donating group (factor A, 44.3\%).

The absorption wavelengths calculated according to the average value and the effects of the corresponding level of each factor (Table 4) are in good agreement with experimental values 
for the compounds described in the literature $(\Delta \lambda<18 \mathrm{~nm}$, see supporting information). For emission, the differences between calculated and experimental values are a bit higher $(\Delta \lambda<$ $39 \mathrm{~nm}$, see supporting information) in particular for the most red-shifted compounds.

\section{$<$ Table 4>}

$<$ Table 5 $>$

In an effort to gain further insight into the photophysical process within this series of pyrimidine push-pull chromophores, we investigated the emission behavior of compounds 1-9 in different aprotic solvents. The results of these investigations are summarized in Table 6. As an example the emission spectra in various solvents for compound $\mathbf{6}$ are shown in Figure 3. For all compounds, the emission maxima were plotted versus the Dimroth-Reichardt polarity parameter $\left(\Delta \mathrm{E}_{\mathrm{T}}(30)\right)$. In all case a good linearity was obtained (see supporting information). The slopes of the corresponding regression lines (SP) are good indications of the intensity of the ICT into the chromophores. The highest value of SP is observed for compound $\mathbf{5}$.

\section{$<$ Table 6> \\ $<$ Figure 4>}

The ANOVA method was employed to study the influence of each factor on the value of SP in a similar manner than for absorption and emission maxima. The results are given in Tables 7 and 8 . The average value of SP is 1.73 . Once again, the influence of the residue is low (2.1\%). Two factors significantly explain SP according to their F-ratios: the nature of the electron-donating group (factor A, $46.8 \%$ ) and of the $\pi$-conjugated core (factor $\mathrm{C}, 40.4 \%$ ). The substituted position of the pyrimidine ring seems to be less important. According to Table 7, the optimal configuration consists in diphenylamino donor groups (level 3 factor A) linked to a 4-6-disubstituted pyrimidine (level 3 factor B) by a biphenylenevinylene bridge (level 3 
factor C). The corresponding structure (compound 12) exhibits a higher SP value than compounds 1-9 which validates the methodology.

$<$ Table 7>

$<$ Table 8>

\section{Conclusion}

To conclude, we have shown that Taguchi design of experiment methodology can be efficiently applied to predict the photophysical properties (absorption and emission maxima) of a family of pyrimidine chromophores. ICT in these compounds estimated by emission solvatochromy has been also optimized using the same approach. Taguchi design of experiment methodology appears useful to study the influence various parameters involved in the photophysical properties of a series of dyes and to identify quickly the optimized chromophore. This strategy could be applied to other family of chromophores. 
Figure 1. General structure of the studied dyes.

Figure 2. Chromophores 1, 2, 3, 4, 5, 6, 7, 8, 9

Figure 3. Absorption (broken line) and emission spectra (solid line) of chromophores 9

Figure 4. Normalized emission spectra of chromophore 6 in various solvents.

Scheme 1. Synthesis of compound 4

Scheme 2. Synthesis of compound 7.

Scheme 3. Synthesis of compound 8.

Scheme 4. Synthesis of compound 12.

Table 1. Parameters and their values corresponding to their levels to be studied in experiments.

Table 2. Experimental layout using the $\mathrm{L}_{9}$ orthogonal array.

Table 3. UV/Vis and photoluminescence (PL) data

Table 4. Effect of each level of each factor on $\lambda_{\text {abs }}$ in $\mathrm{nm}$

Table 5. Analysis of variance (ANOVA) for on $\lambda_{\text {abs }}$ in $\mathrm{nm}$.

Table 6. Emission solvatochromic range of pyrimidine chromophores 1-9 and $\mathbf{1 2}$ in various aprotic solvents

Table 7. Effect of each level of each factor on SP

Table 8. Analysis of variance of SP 
[1]a) Gompper R, Wagner HU. Donor-Acceptor-Substituted $\pi$-Electron Systems-Probes for Theories and Building Blocks for New Materials. Angew Chem Int Ed Engl 1988;27:143755. b) Kivala M, Diederich F. Acetylene-derived strong organic acceptors for planar and nonplanar push-pull chromophores. Acc Chem Res;42:235-48.

[2]Kulhánek J, Bureš F, Opršal J, Kuznik W, Mikysek T, Růžička A. 1,4-Phenylene and 2,5thienylene $\pi$-linkers in charge-transfer chromophores. Asian J Org Chem 2013;2:422-31.

[3]See for example : a) Guliyev R, Coskun A, Akkaya EU, Design strategies for ratiometric chemosensors: modulation of excitation energy transfer at the energy donor site. J Am Chem Soc 2009;131:9007-13. b) Costero AM, Parra M, Gil S, Gotor R, Mancini PME, MartínezMáñez R, Sancenón F, Royo S. Chromo-fluorogenic detection of nerve-agent mimics using triggered cyclization reactions in push-pull dyes. Chem Asian J 2010;5:1573-85. c) Hadad C, Achelle S, López-Solera I, García-Martínez JC. Metal cation complexation studies of 4arylvinyl-2,6-di(pyridin-2-yl)pyrimidines: effect on the optical properties. Dyes Pigm 2013:97:230-7. d) Nepraš M, Almonasy N, Bureš F, Kulhánek J, Dvořák M, Michl M. Fluorescence and photophysical properties of D- $\pi$-A push-pull systems featuring a 4,5dicyanoimidazole unit. Dyes Pigm 2011;91:466-73. e) Denneval C, Moldovan O, Baudequin C, Achelle S, Baldeck P, Plé N, Darabantu M, Ramondenc Y. Synthesis and photophysical properties of push-pull structures incorporating diazines as attracting part with a fluorene core. Eur J Org Chem 2013;5591-06.

[4] a) Lin Y, Li Y, Zhan X. Small molecule semiconductors for high-efficiency organic photovoltaics. Chem Soc Rev 2012;41:4245-72. b) Hagfeldt A, Boschloo G, Sun L, Kloo L, Pettersson H. Dye-sensitized solar cells. Chem Rev 2010;110:6595-663. c) Günes S, Neugebauer H, Sariciftci NS. Conjugated polymer-based organic solar cells. Chem Rev 2007;107:1324-38. 
[5] a) Walzer K, Maennig B, Pfeiffer M, Leo K. Highly efficient organic devices based on electrically doped transport layers. Chem Rev 2007;107:1233-71. b) Yang Y, Zhou Y, He QG, He C, Yang CH, Bai FL, Li YF. Solution-processable red-emission organic materials containing triphenylamine and benzothiodiazole units: synthesis and applications in organic light-emitting diodes. J Phys Chem B 2009;113:7745-52.

[6] a) Barlow S, Marder SR. Nonlinear Optical Properties of Organic Materials. In: Functional Organic Materials; Müller, TJJ, Bunz UHF, Eds.; Wiley-VCH: Weinheim, Germany, 2007; p. 393-437. b) Szablewski M, Thomas PR, Thornton A, Bloor D, Cross GH, Cole JM, Howard JAK, Malagoli M, Meyers F, Brédas JL, Wenseleers W, Goovaerts E. Highly dipolar, optically nonlinear adducts of tetracyano- $p$-quinodimethane: synthesis, physical characterization, and theoretical aspects. J Am Chem Soc 1997:119;3144-54. c) Tykwinski RR, Gubler U, Martin RE, Diederich F, Bosshard C, Günter P. Structure-property relationships in third-order nonlinear optical chromophores. J Phys Chem B 1998;102:445165.

[7] a) Taniuchi T, Okada S, Nakanishi H. Widely tunable terahertz-wave generation in an organic crystal and its spectroscopic application. J Appl Phys 2004;95:5984-8. b) Taniuchi T, Ikeda S, Mineno Y, Okada S, Nakanishi H. Terahertz properties of a new organic crystal, 4'dimethylamino- $N$-methyl-4-stilbazolium $\quad p$-chlorobenzenesulfonate. Jpn J Appl Phys 2005;44:L932-4. c) Schneider A, Stillhart M, Günter P. High efficiency generation and detection of terahertz pulses using laser pulses at telecommunication wavelengths. Opt Express 2006;14:5376-84. d) Yang Z, Mutter L, Stillhart M, Ruiz B, Aravazhi S, Jazbinsek M, Schneider A, Gramlich V, Günter P. Large-size bulk and thin-film stilbazolium-salt single crystals for nonlinear optics and THz generation. Adv Funct Mater 2007;17:2018-23.

[8] a) He GS, Tan LS, Zheng Q, Prasad PN. Multiphoton absorbing materials: molecular designs, characterizations, and applications. Chem Rev 2008;108:1245-330. b) Malval JP, Jin 
M, Morlet-Savary F, Chaumeil H, Defoin A, Soppera O, Scheul T, Bouriau M, Baldeck PL. Enhancement of the two-photon initiating efficiency of a thioxanthone derivative through a chevron-shaped architecture. Chem. Mater. 2011;23:3411-20. c) Kobayashi K, Kano SS. Multilayered optical storage with nonlinear read write. Opt Rev 1995;2:20-3.

[9] Paley MS, Harris JM, Looser H, Baumert JC, Bjorklund GC, Jundt D, Twieg RJ. A solvatochromic method for determining second-order polarizabilities of organic molecules. $\mathbf{J}$ Org Chem 1989;54:3774-8.

[10] a) Achelle S, Plé N. Pyrimidine ring as building block for the synthesis of functionalized Pi-conjugated materials. Curr Org Synth 2012;9:163-87. b) Achelle S, Baudequin C. Recent advances in pyrimidine derivatives as luminescent, photovoltaic and non-linear optical materials. Targets Heterocycl Systems 2013;17:under press.

[11] See for example: a) Achelle S, Ramondenc Y, Marsais F, Plé N. Star- and banana-shaped oligomers with a pyrimidine core: synthesis and light-emitting properties. Eur J Org Chem 2008;3129-40.b) Itami K, Yamazaki D, Yoshida Ji. Pyrimidine-core extended $\pi$-systems: general synthesis and interesting fluorescent properties. J Am Chem Soc 2004;126:15396-7.

c) Bagley MC, Lin Z, Pope SJA. Barium manganate in microwave-assisted oxidation reactions: synthesis of solvatochromic 2,4,6-triarylpyrimidines. Tetrahedron Lett 2009;50:6818-22. d) Tumkevičius S, Voitechovičius A, Adomènas P, Synthesis of novel 2,4,6-triarylpyrimidines Chemija 2012;23:61-7.

[12] see for example a) Liu B, Hu XL, Liu J, Zhao YD, Huang ZL. Synthesis and photophysical properties of novel pyrimidine-based two-photon absorption chromophores. Tetrahedron Lett 2007;48:5958-62. b) Li L, Ge J, Wu H, Xu QH, Yao S Q. Organelle-specific detection of phosphatase activities with two-photon fluorogenic probes in cells and tissues. $\mathrm{J}$ Am Chem Soc 2012;134:12157-67. c) Achelle S, Malval JP, Aloïse S, Barsella A, Spangenberg A, Mager L, Akdas-Killig H, Fillaut JL, Caro B, Robin-le Guen F. Synthesis, 
photophysics and nonlinear optical properties of stilbenoid pyrimidine-based dyes bearing methylenepyran donor groups. ChemphysChem 2013;14:2725-36.

[13] a) Achelle S, Barsella A, Baudequin C, Caro B, Robin-le Guen F. Synthesis and photophysical investigation of a series of push-pull arylvinyldiazine chromophores. J Org Chem 2012;77:4087-96. b) Castet F, Pic A, Champagne B, Linear and nonlinear optical properties of arylvinyldiazine dyes: a theoretical investigation. Dyes Pigm doi: 10.1016/j.dyepig.2014.03.021

[14] a) Bureš F, Pytela O, Diederich F. Solvent effects on electronic absorption spectra of donor-substituted 11,11,12,12-tetracyano-9,10-anthraquinodimethanes (TCAQs) J Phys Org Chem 2009;22:155-62. b) Bureš F, Pytela O, Kivala M, Diederich F. Solvatochromism as an efficient tool to study $\mathrm{N}, \mathrm{N}$-dimethylamino- and cyano-substituted $\pi$-conjugated molecules with an intramolecular charge-transfer absorption J Phys Org Chem 2011;24:274-81.

[15] a) Lartia R, Allain C, Bordeau G, Schmidt F, Fiorini-Debuisschert, Charra F, TeuladeFichou MP. Synthetic strategies to derivatizable triphenylamines displaying high two-photon absorption. J Org Chem 2008;73:1732-44. b) Katan C, Terenziani F, Mongin O, Werts MHV, Porrès L, Pons T, Mertz J, Tretiak S, Blanchard-Desce M. Effects of (multi)branching of dipolar chromophores on photophysical properties and two-photon absorption. J Phys Chem A 2005;109:3024-3037. c) Detert H, Schmitt V. Quadrupolar donor-acceptor substituted oligo(phenylenevinylene)s-synthesis and solvatochromism of the fluorescence. J Phys Org Chem 2004;17:1051-6.

[16] a) Katritzky AR, Fara DC, Yang H, Tämm K. Quantitative measures of solvent polarity. Chem Rev 2004;104:175-98. b) Mancini PM, Adam CG, Fortunato GG, Vottero LR. A comparison of nonspecific solvent scales. Degree of agreement of microscopic polarity values obtained by different measurement methods. Arkivoc 2007;xvi:266-80. 
[17] a) Reichardt C. Solvatochromic dyes as solvent polarity indicators. Chem Rev 1994;94:2319-58. b) Cerón-Carrasco JP, Jacquemin D, Laurence C, Planchat A, Reichardt C, Sraïdi K. Solvent polarity scales : determination of new $\mathrm{E}_{\mathrm{T}}(30)$ values for 84 organic solvents. J Phys Org Chem 2014;27:512-8.

[18] a) Taguchi G (ed.). System of experimental design. White Plains, NJ: Quality Resources Press;1987. b) Taguchi G (ed.). Taguchi methods: orthogonal arrays and linear graphs (softcover edn). Dearborn, Mich, USA: American Supplier Institute;1987. c) Ross PJ (ed.). Taguchi techniques for quality engineering (hardcover edn). City of New York, New York, USA: McGraw-Hill; 1996.

[19] See for example a) Pourjavadi A, Ayyari M, Amini-Fazl MS. Taguchi optimized synthesis of collagen-g-poly(acrylic acid)/kaolin composite superabsorbent hydrogel. Eur Polym J 2008;44:1209-16. b) Masoumi HRF, Kassim A, Basri M, Abdullah DK. Determining optimum conditions for lipase-catalyzed synthesis of triethanolamine (TEA)-based esterquat cationic surfactant by a Taguchi robust design method. Molecules 2011;16:4672-80. c) Drogat N, Barrière M, Granet R, Sol V, Krausz P. High yield preparation of purpurin-18 from Spirulina maxima. Dyes Pigm 2011;88:125-7.

[20] Kulhánek J, Bureš F, Pytela O, Mikysek T, Ludvík J, Růžička A. Puh-Pull molecules with a systematically extended $\pi$-conjugated system featuring 4,5-dicyanoimidazole. Dyes Pigm 2010;85:57-65.

[21] Chen L, Chu CI, Chen KJ, Chen PY, Hu SF, Liu RS. An intelligent approach to the discovery of luminescent materials using combinatorial approach combined with Taguchi methodology. Luminescence 2011;26:229-38.

[22] Zheng X, Song B, Xu B. Palladium-catalyzed regioselective C-H Bond orthoacetoxylation of arylpyridines 2010;4376-80. 
[23] Pascal L, Vanden Eynde JJ, Van Haverbeke Y, Dubois P, Michel A, Rant U, Zojer E, Leising G, Van Dorn LO, Gruhn NE, Cornil J, Brédas JL. Synthesis and characterization of novel para- and meta-phenylenevinylene derivatives: fine tuning of the electronic and optical properties of conjugated materials. J Phys Chem B 2002;106:6442-50.

[24] Achelle S, Nouira I, Pfaffinger B, Ramondenc Y, Plé N, Rodríguez-López J. V-shaped 4,6-bis(arylvinyl)pyrimidine oligomers: synthesis and optical properties. J Org Chem 2009;74:3711-7. 


\begin{tabular}{l} 
Parameter \\
\cline { 2 - 4 } \\
A: Nature of electron- \\
donating group
\end{tabular}




\begin{tabular}{ccccc}
\hline Compound & A & B & C & D \\
\hline $\mathbf{1}$ & 1 & 1 & 1 & 1 \\
$\mathbf{2}$ & 1 & 2 & 2 & 2 \\
$\mathbf{3}$ & 1 & 3 & 3 & 3 \\
$\mathbf{4}$ & 2 & 1 & 2 & 3 \\
$\mathbf{5}$ & 2 & 2 & 3 & 1 \\
$\mathbf{6}$ & 2 & 3 & 1 & 2 \\
$\mathbf{7}$ & 3 & 1 & 3 & 2 \\
$\mathbf{8}$ & 3 & 2 & 1 & 3 \\
$\mathbf{9}$ & 3 & 3 & 2 & 1 \\
\hline
\end{tabular}




\begin{tabular}{clccc}
\hline & \multicolumn{1}{c}{$\mathrm{UV} / \mathrm{vis} \lambda_{\max }, \mathrm{nm}$} & $\mathrm{PL}$ & & Stokes shift \\
$\mathrm{Compd}^{a}$ & \multicolumn{1}{c}{$\left(\varepsilon, \mathrm{M}^{-1} \cdot \mathrm{cm}^{-1}\right)$} & $\lambda_{\max }, \mathrm{nm}$ & $\Phi_{\mathrm{F}}{ }^{b}$ & $\mathrm{~cm}^{-1}$ \\
\hline $\mathbf{1}$ & $283(26600)$ & 356 & $<0.01$ & 7245 \\
$\mathbf{2}$ & $338(28500)$ & 418 & $<0.01$ & 5662 \\
$\mathbf{3}^{b}$ & $373(60500)$ & 483 & 0.59 & 6106 \\
$\mathbf{4}$ & $251(18900), 379(31900)$ & 472 & 0.01 & 5199 \\
$\mathbf{5}^{c}$ & $296(24600), 386(32400)$ & 570 & 0.66 & 8362 \\
$\mathbf{6}$ & $299(16000), 378(38100)$ & 429 & 0.72 & 3145 \\
$\mathbf{7}$ & $303(38400), 373(36500)$ & 530 & 0.60 & 7942 \\
$\mathbf{8}$ & $300(13000), 367(31400)$ & 482 & 0.55 & 6501 \\
$\mathbf{9}^{b}$ & $301(38900), 427(47600)$ & 540 & 0.55 & 4901 \\
\hline
\end{tabular}

${ }^{a}$ All spectra were recorded in $\mathrm{CH}_{2} \mathrm{Cl}_{2}$ solutions at room temperature at $c=1.0 \times 10^{-5}$ $\mathrm{M}$ to $3.0 \times 10^{-5} \mathrm{M}$ for absorption and $c=1.0 \times 10^{-6} \mathrm{M}$ to $3.0 \times 10^{-6} \mathrm{M}$ for emission. ${ }^{b}$ Fluorescence quantum yield $( \pm 10 \%)$ determined relative to quinine sulfate in $1 \mathrm{M}$ $\mathrm{H}_{2} \mathrm{SO}_{4}\left(\Phi_{\mathrm{F}}=0.54\right)$ or harmane in $0.1 \mathrm{M} \mathrm{H}_{2} \mathrm{SO}_{4}$ as standard $\left(\Phi_{\mathrm{F}}=0.83\right){ }^{b}$ data from ref [24]. ${ }^{\circ}$ data from ref [13a]. 


\begin{tabular}{cccccc}
\hline factor & $\mathrm{S}^{a}$ & $\operatorname{dof}^{b}$ & $\mathrm{~V}^{c}$ & F-ratio $^{d}$ & ${\text { Explained } \%^{e}}^{c}$ \\
\hline A & 5856 & 2 & 2928 & 35.6 & 48.0 \\
B & 3462 & 2 & 1731 & 21.1 & 28.4 \\
C & 2713 & 2 & 1356 & 16.5 & 22.2 \\
Residue & 164 & 2 & 82 & & 1.3 \\
Total & 12281 & 8 & & 100 \\
\hline
\end{tabular}

${ }^{a}$ Sum of squared deviations from the mean. ${ }^{b}$ degree of freedom. ${ }^{c}$ variance: mean of squares per dof. ${ }^{d}$ ratio between squared deviation and the mean of square residue. ${ }^{e}$ relative effects of the factors on $\lambda_{\text {abs }}$. 


\begin{tabular}{ccccccc}
\hline & \multicolumn{2}{c}{ A } & \multicolumn{2}{c}{ B } & \multicolumn{2}{c}{ C } \\
& Average & Effect & Average & Effect & Average & Effect \\
\hline 1 & 331 & -36 & 345 & -22 & 343 & -24 \\
2 & 381 & 14 & 364 & -3 & 381 & 14 \\
3 & 389 & 22 & 393 & 26 & 377 & 10 \\
\hline
\end{tabular}




\begin{tabular}{|c|c|c|c|c|c|c|}
\hline & $\begin{array}{c}n \text {-heptane } \\
\Delta \mathrm{E}_{\mathrm{T}}(30)^{a}=0.0 \\
\lambda_{\mathrm{em}}(\mathrm{nm})\end{array}$ & $\begin{array}{c}\text { Toluene } \\
\Delta \mathrm{E}_{\mathrm{T}}(30)^{a}=13.6 \\
\lambda_{\mathrm{em}}(\mathrm{nm})\end{array}$ & $\begin{array}{c}\mathrm{THF} \\
\Delta \mathrm{E}_{\mathrm{T}}(30)^{a}=27.2 \\
\lambda_{\mathrm{em}}(\mathrm{nm})\end{array}$ & $\begin{array}{c}\mathrm{CH}_{2} \mathrm{Cl}_{2} \\
\Delta \mathrm{E}_{\mathrm{T}}(30)^{a}=40.7 \\
\lambda_{\mathrm{em}}(\mathrm{nm})\end{array}$ & $\begin{array}{c}\text { DMSO } \\
\Delta \mathrm{E}_{\mathrm{T}}(30)^{a}=59.0 \\
\lambda_{\mathrm{em}}(\mathrm{nm})\end{array}$ & $\mathrm{SP}^{b}$ \\
\hline 1 & $-^{c}$ & $-^{c}$ & 352 & 356 & $-^{c}$ & 0.30 \\
\hline 2 & 384 & 401 & 410 & 418 & 427 & 0.70 \\
\hline 3 & 405 & 422 & 458 & 483 & 509 & 1.85 \\
\hline 4 & 423 & 439 & 460 & 472 & 497 & 1.25 \\
\hline 5 & 453 & 490 & 554 & 569 & 632 & 3.01 \\
\hline 6 & 373 & 403 & 431 & 435 & 480 & 1.70 \\
\hline 7 & 418 & 458 & 498 & 530 & 566 & 2.52 \\
\hline 8 & 400 & 430 & 456 & 482 & 509 & 1.85 \\
\hline 9 & 443 & 476 & 515 & 540 & 584 & 2.38 \\
\hline 12 & 440 & 481 & 545 & 585 & 623 & 3.43 \\
\hline
\end{tabular}

${ }^{a}$ Dimroth-Reichardt polarity parameter, $\mathrm{J} \cdot \mathrm{mol}^{-1} .{ }^{b} \mathrm{SP}$ : slope of the regression line $\lambda_{\mathrm{em}}(\mathrm{nm})$

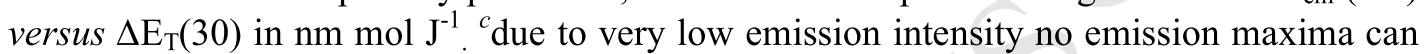
be obtained. 


\begin{tabular}{ccccccc}
\hline & \multicolumn{2}{c}{ A } & \multicolumn{2}{c}{ B } & \multicolumn{2}{c}{ C } \\
& Average & Effect & Average & Effect & Average & Effect \\
\hline 1 & 0.95 & -0.78 & 1.36 & -0.37 & 1.28 & -0.45 \\
2 & 1.99 & 0.26 & 1.85 & 0.12 & 1.44 & -0.29 \\
3 & 2.25 & 0.52 & 1.98 & 0.25 & 2.46 & 0.73 \\
\hline
\end{tabular}




\begin{tabular}{cccccc}
\hline Factor & $\mathrm{S}^{a}$ & dof $^{b}$ & $\mathrm{~V}^{c}$ & F-ratio $^{d}$ & ${\text { Explained } \%^{e}}^{e^{c}}$ \\
\hline A & 2.834 & 2 & 1.42 & 22.3 & 46.8 \\
B & 0.645 & 2 & 0.32 & 5.10 & 10.7 \\
C & 2.444 & 2 & 1.22 & 19.3 & 40.4 \\
Residue & 0.127 & 2 & 0.03 & & 2.1 \\
Total & 6.051 & 8 & & & 100 \\
\hline
\end{tabular}

${ }^{a}$ Sum of squared deviations from the mean. ${ }^{b}$ degree of freedom, ${ }^{c}$ variance: mean of squares per dof. ${ }^{d}$ ratio between squared deviation and the mean of square residue. ${ }^{e}$ relative effects of the factors on SP. 
戠 $\pi$-conjugated linker $R$

$\mathrm{R}=$ electron-donating group 

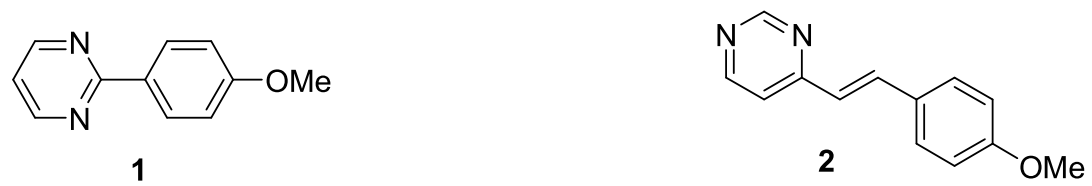<smiles>CCCCOc1ccc(-c2ccc(/C=C/c3cc(/C=C/c4ccc(-c5ccc(OCC)cc5)cc4)ncn3)cc2)cc1</smiles><smiles>CC(=O)N1C=CC(c2ccc(/C=C/c3ccncn3)cc2)CC1</smiles><smiles>CNc1ccc(C2=CC(c3ccc(N(C)C)cc3)N3CCN=CN2C3)cc1</smiles><smiles>C(=C/c1ncccn1)\c1ccc(-c2ccc(N(c3ccccc3)c3ccccc3)cc2)cc1</smiles><smiles>PN(c1ccccc1)c1ccc(-c2cccnc2)cc1</smiles><smiles>Cc1cc(/C=C/c2ccc(N(c3ccccc3)c3ccccc3)cc2)ncn1</smiles> 


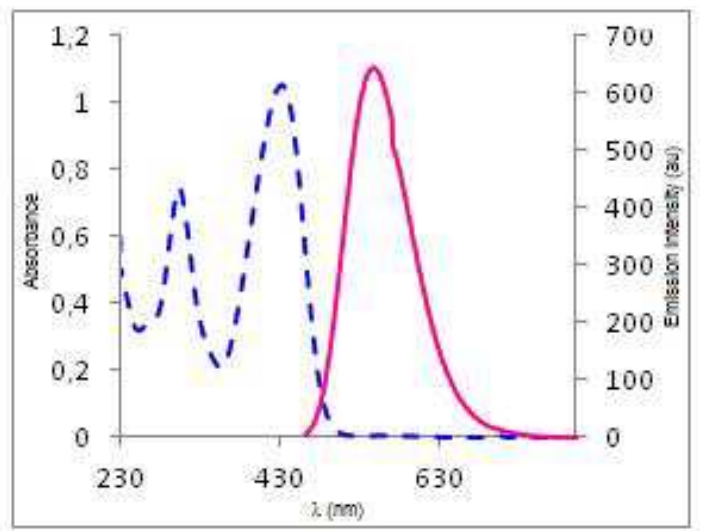




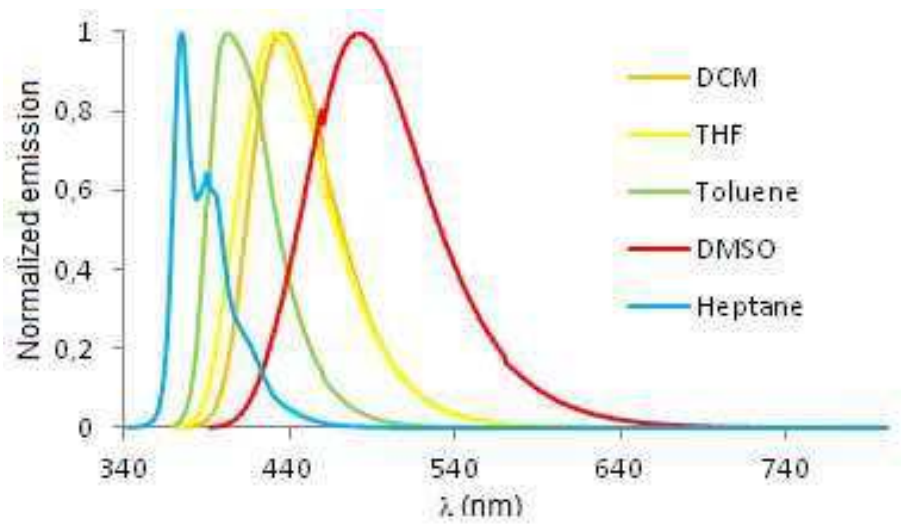




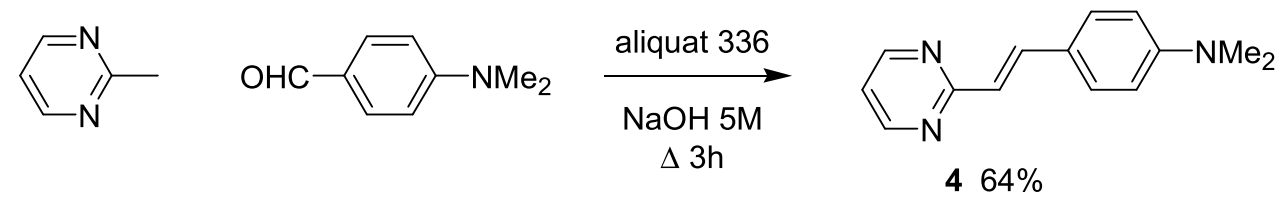




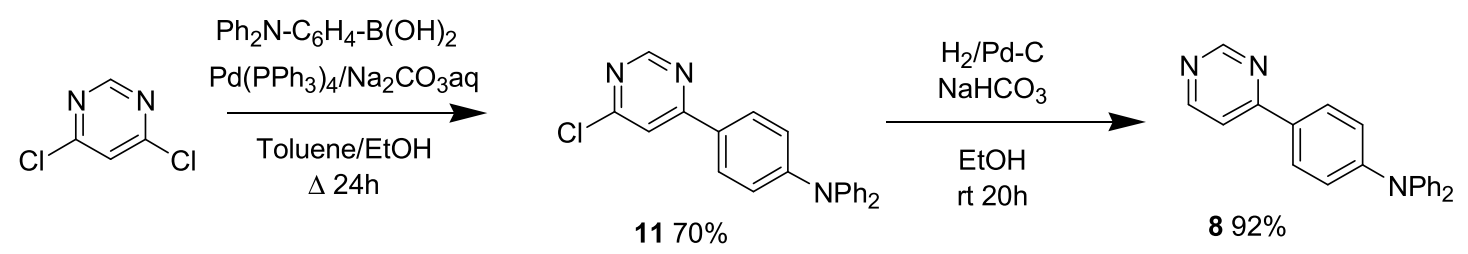




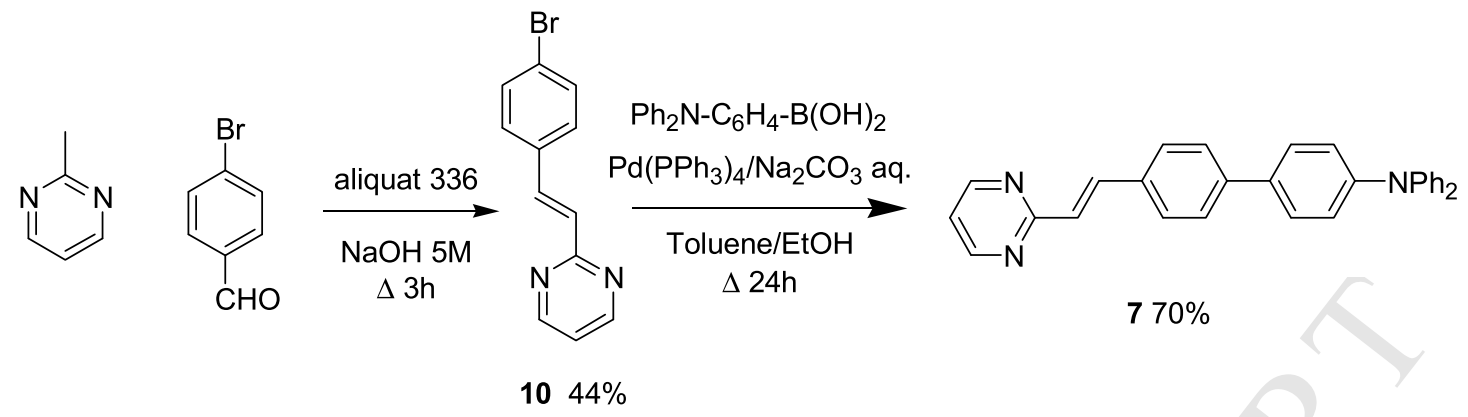




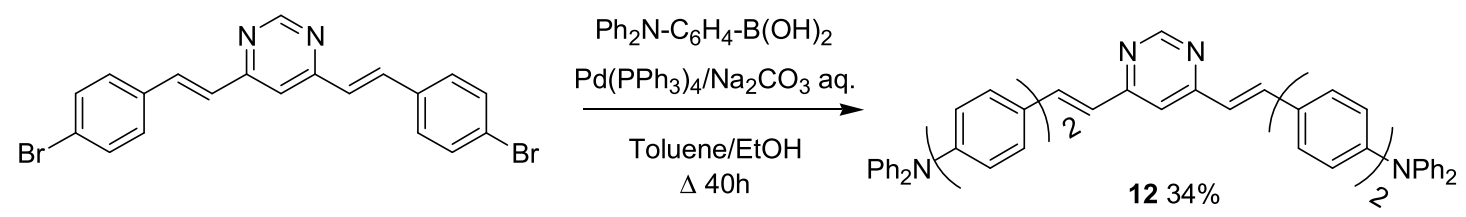


The photophysical properties of pyrimidine chromophores have been studied.

The influence of three parameters has been studied by Taguchi methodology.

Internal charge transfer estimated by emission solvatochromy has been optimized. 


\section{Prediction of photophysical properties of pyrimidine chromophores using Taguchi method.}

Charline Denneval, ${ }^{1}$ Sylvain Achelle, ${ }^{2 *}$ Christine Baudequin, ${ }^{1}$ and Françoise Robin-le Guen. ${ }^{2}$

${ }^{1}$ Normandie Univ. COBRA, UMR 6014 et FR 3038; Univ. Rouen; INSA Rouen; CNRS, IRCOF, 1 rue Tesnière, 76821 Mont Saint Aignan Cedex, France

${ }^{2}$ Institut des Sciences Chimiques de Rennes UMR CNRS 6226, IUT de Lannion, rue Edouard Branly, BP 30219, F22302 Lannion Cedex, France

Corresponding author: sylvain.achelle@univ-rennes1.fr Tel: +33 (0)2 96469448 Fax : + 33

(0)296469354.

\section{Electronic supporting informations}

Effect of each level of each factor on $\lambda_{\text {em }}$ in $\mathbf{n m}$

Analysis of variance (ANOVA) for on $\lambda_{\mathrm{em}}$ in $\mathrm{nm}$.

Calculated and experimental photophysical data (in $\mathrm{CH}_{2} \mathrm{Cl}_{2}$ ) from literature of some pyrimidine chromophores.

$\lambda_{\text {em }}(\mathrm{nm})$ versus $\Delta \mathbf{E}_{\mathrm{T}}(30)(\mathrm{J} / \mathrm{mol})$ for compounds $1-9$ and 12

Copy of ${ }^{1} \mathrm{H}$ and ${ }^{13} \mathrm{C}$ NMR spectra of compounds 4, 7, 8 and 10-12 S6

References

S11

Table S1. Effect of each level of each factor on $\lambda_{\mathrm{em}}$ in $\mathrm{nm}$ $\mathrm{A} \quad \mathrm{B}$ $\mathrm{C}$

\begin{tabular}{ccccccc} 
& Average & Effect & Average & Effect & Average & Effect \\
\hline 1 & 419 & -57 & 453 & -24 & 424 & -52 \\
2 & 492 & 16 & 490 & 14 & 477 & 0
\end{tabular}


Table S2. Analysis of variance (ANOVA) for on $\lambda_{\mathrm{em}}$ in $\mathrm{nm}$.

\begin{tabular}{cccccc}
\hline Factor & $\mathrm{S}^{\mathrm{a}}$ & dof $^{\mathrm{b}}$ & $\mathrm{V}^{\mathrm{c}}$ & F-ratio $^{\mathrm{d}}$ & ${\text { Explained }{ }^{\mathrm{e}}}^{\mathrm{c}}$ \\
\hline $\mathrm{A}$ & 15672 & 2 & 7836 & 13.2 & 44.3 \\
$\mathrm{~B}$ & 2520 & 2 & 1260 & 2.13 & 7.1 \\
$\mathrm{C}$ & 16017 & 2 & 8009 & 13.5 & 45.3 \\
Residue & 1183 & 2 & 591 & & 3.3 \\
Total & 35394 & 8 & & & 100
\end{tabular}

${ }^{a}$ Sum of squared deviations from the mean ${ }^{b}$ degree of freedom ${ }^{c}$ variance: mean of squares per dof ${ }^{d}$ ratio between squared deviation and the mean of square residue ${ }^{\mathrm{e}}$ relative effects of the factors on $\lambda_{\text {em }}$.

Table S3. Calculated and experimental photophysical data (in $\mathrm{CH}_{2} \mathrm{Cl}_{2}$ ) from literature of some pyrimidine chromophores. ${ }^{1}$

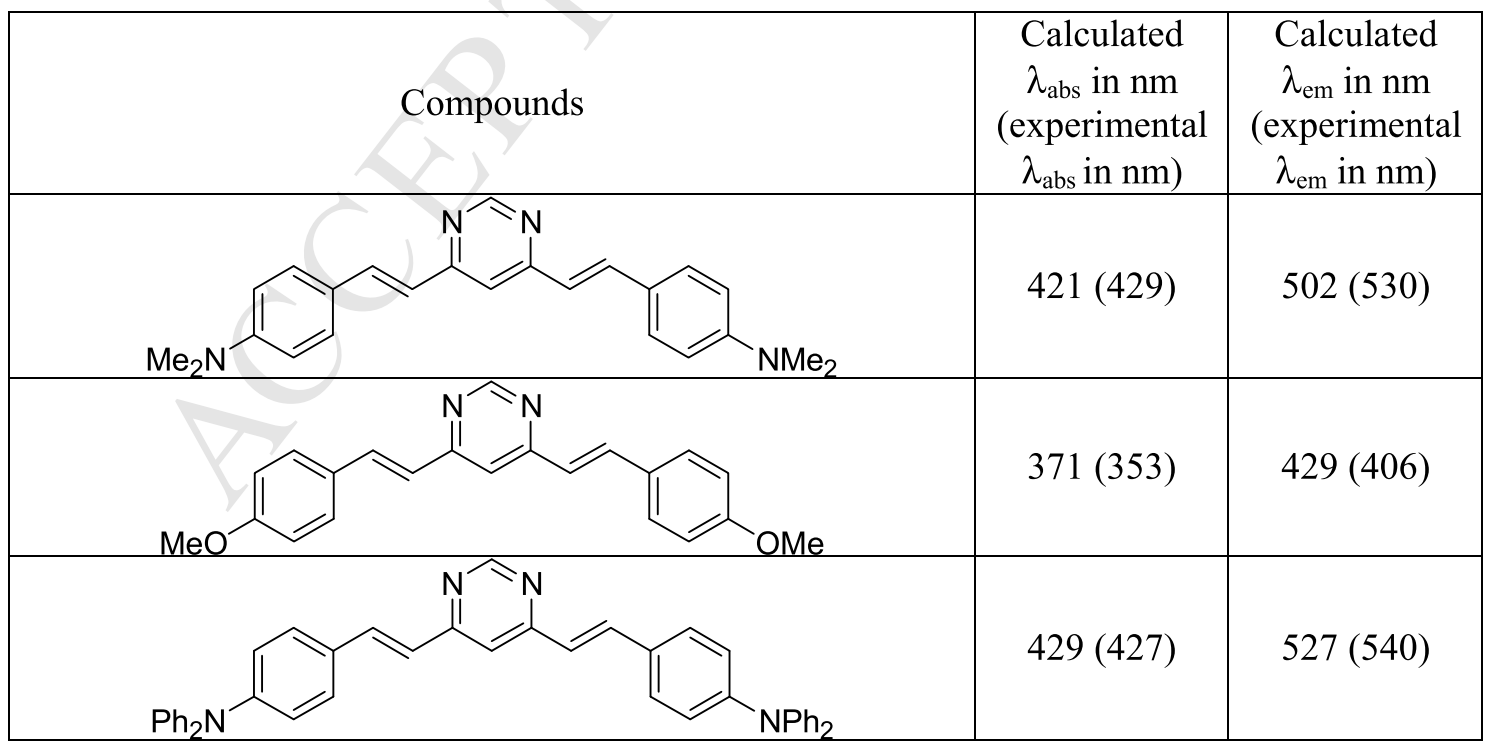


ACCEPTED MANUSCRIPT

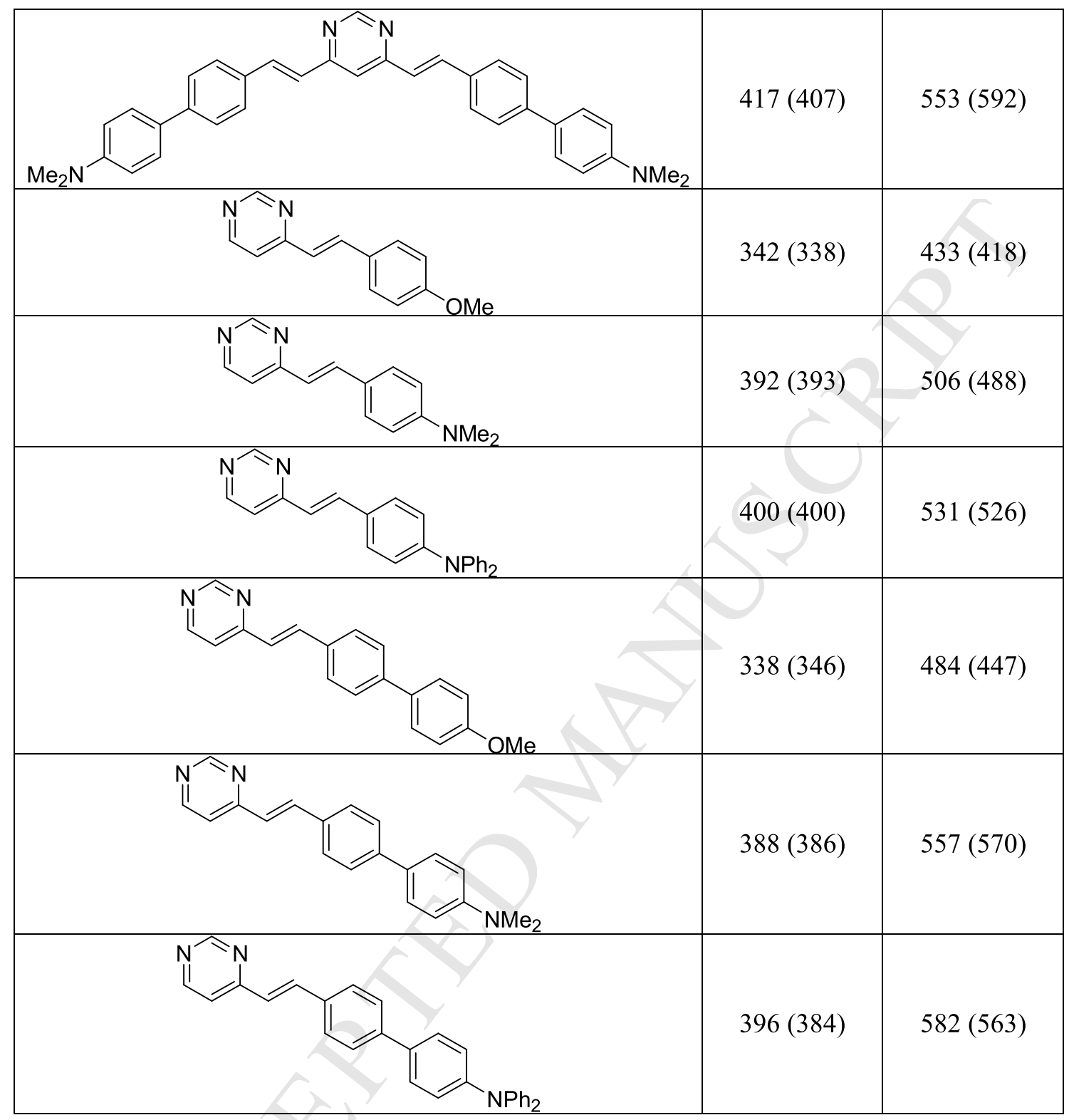



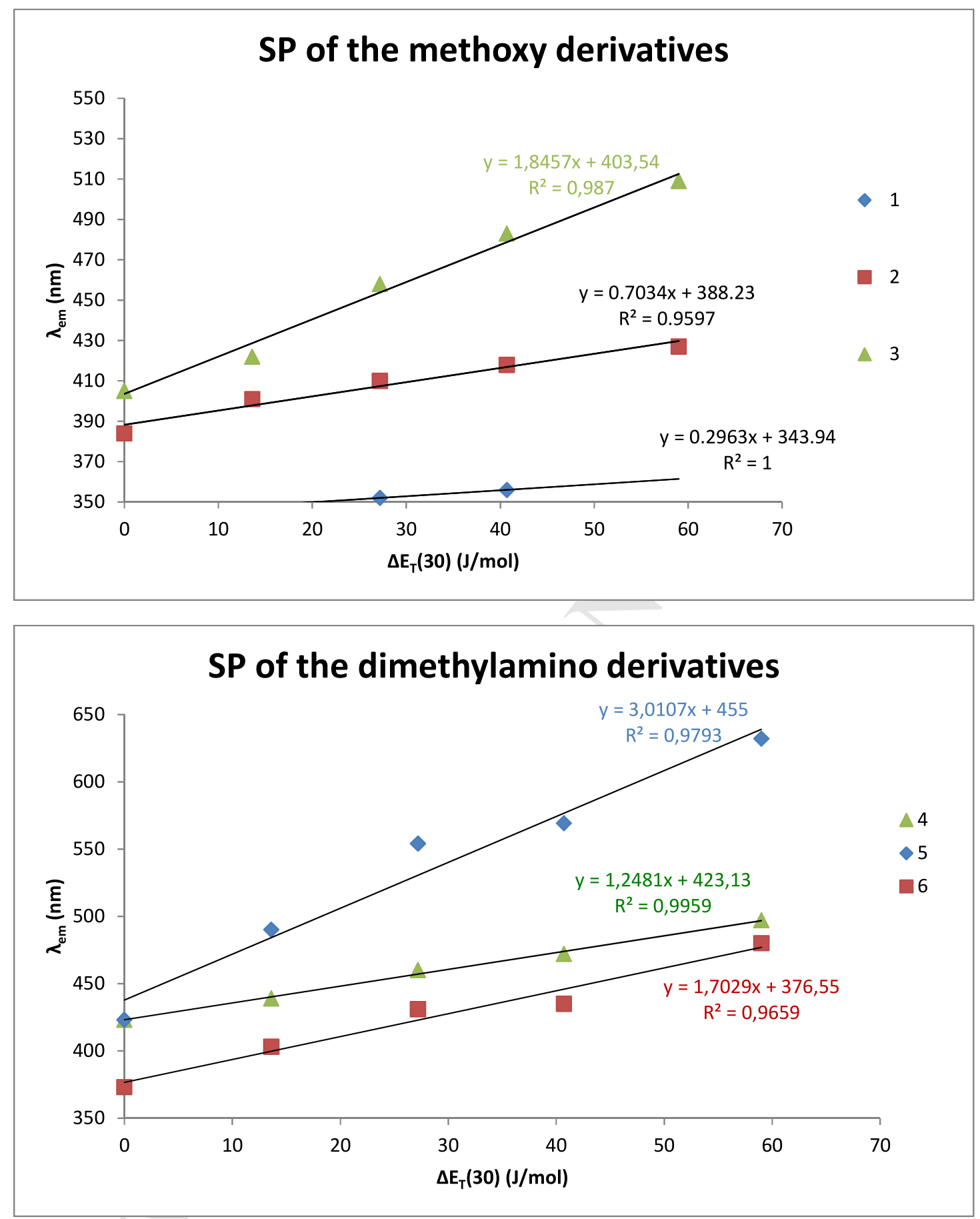

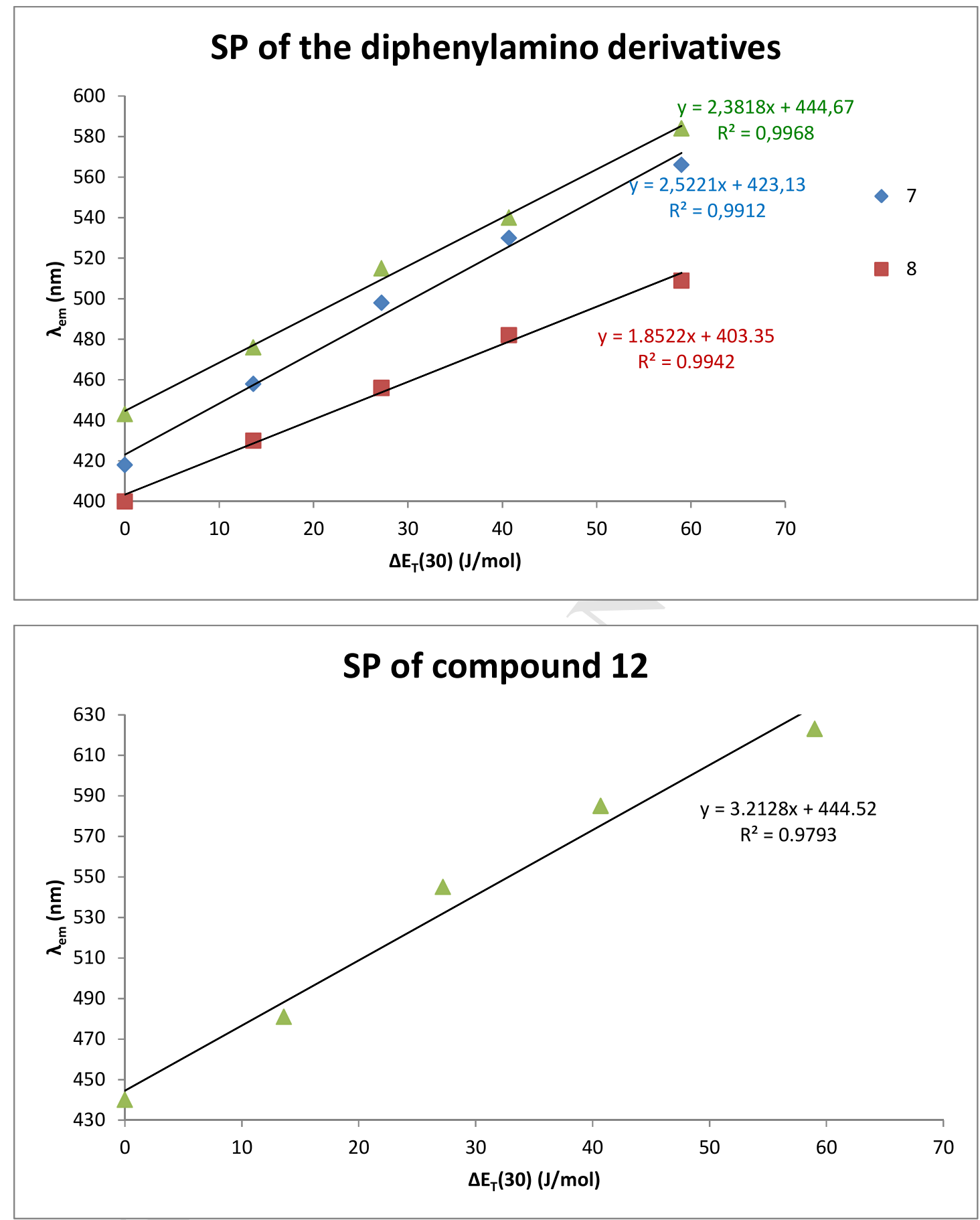

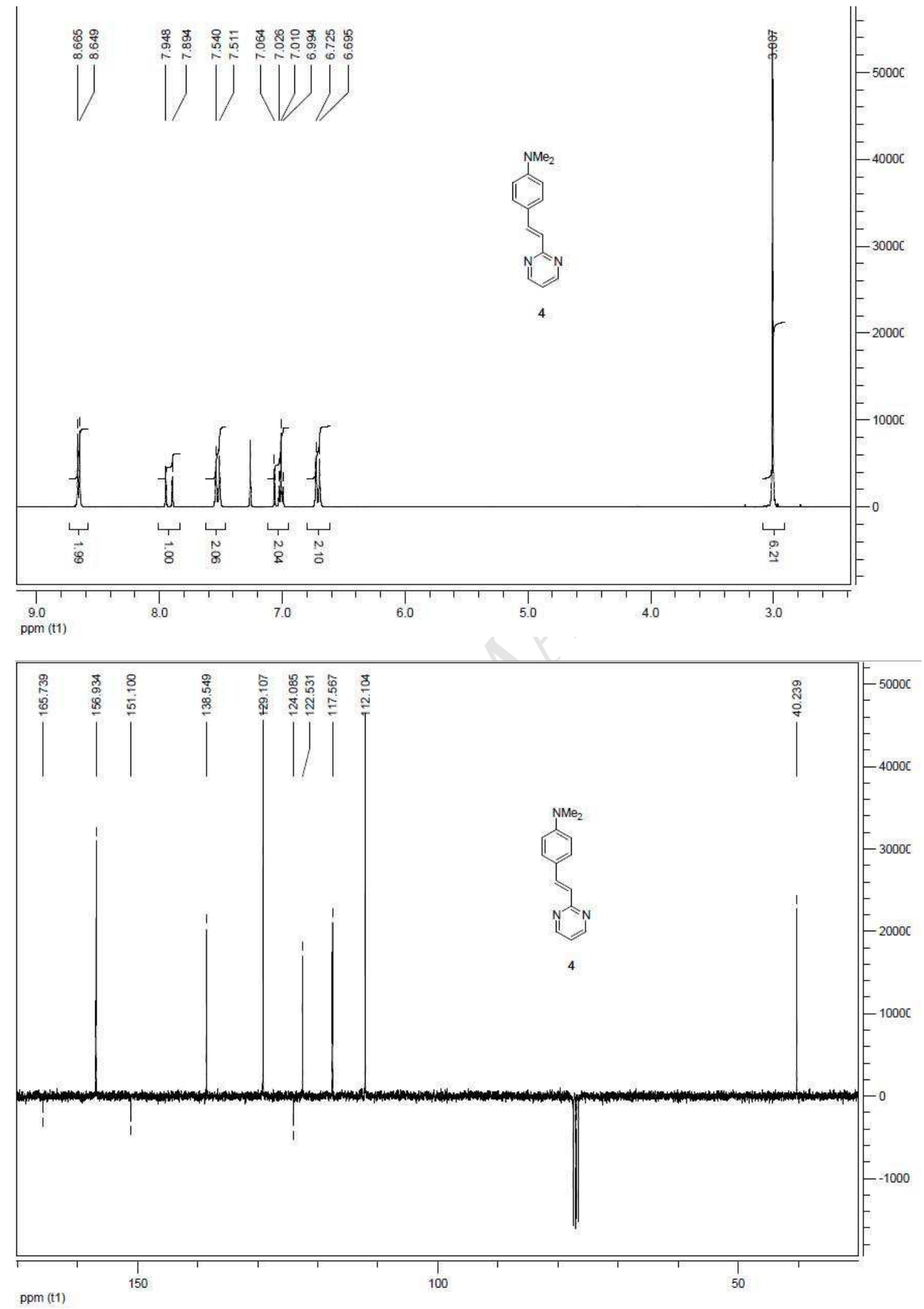


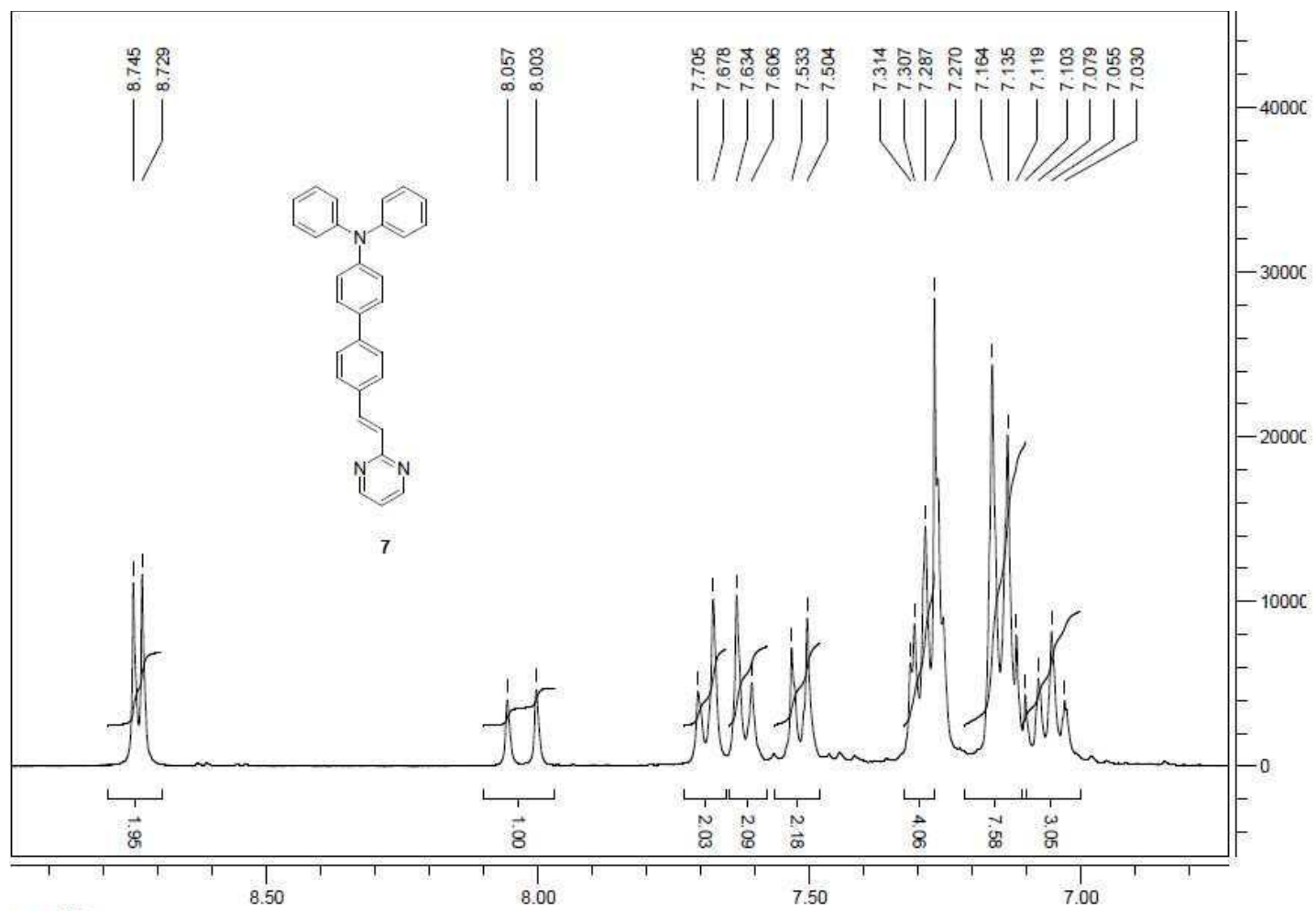

ppm (t1)

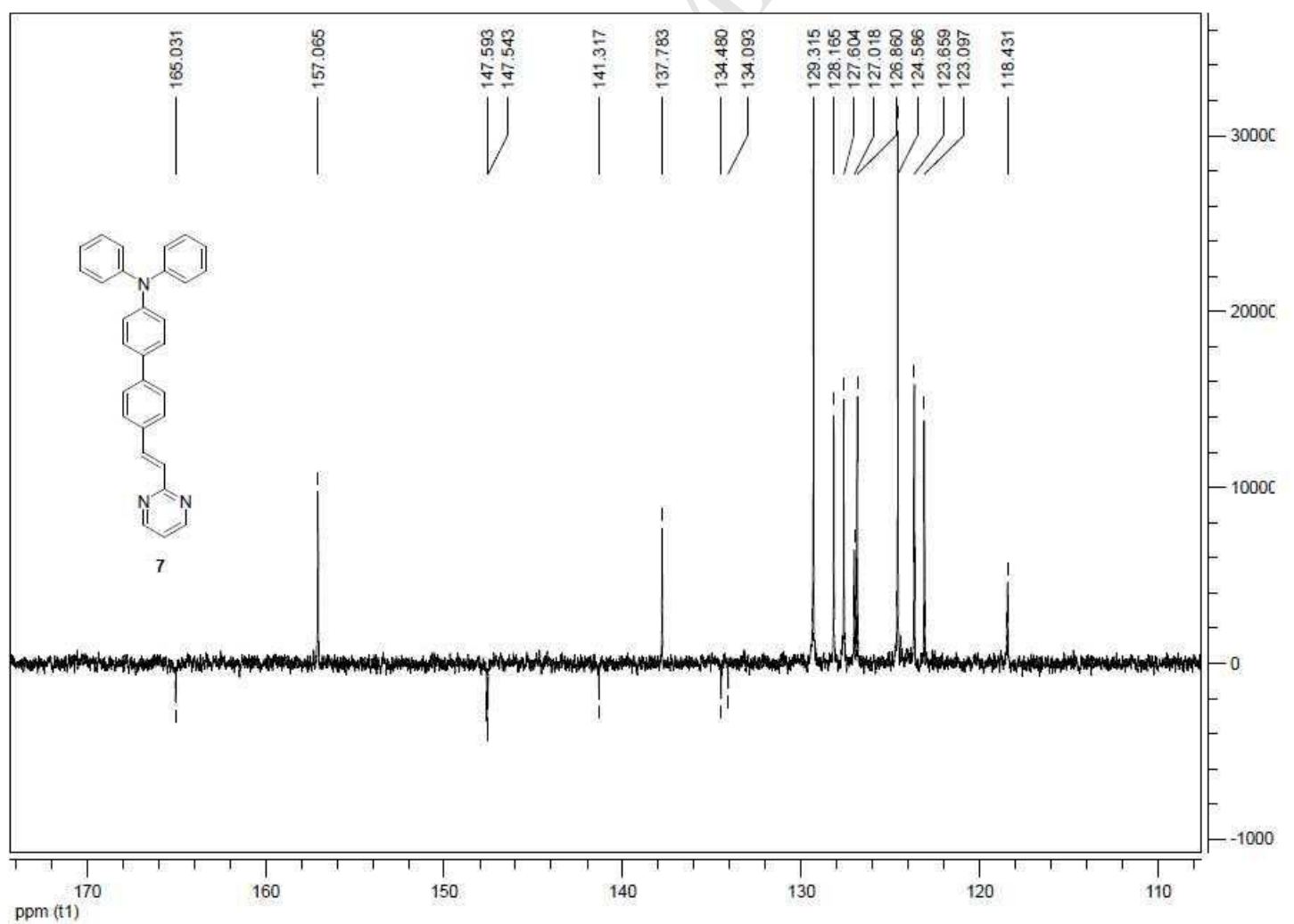




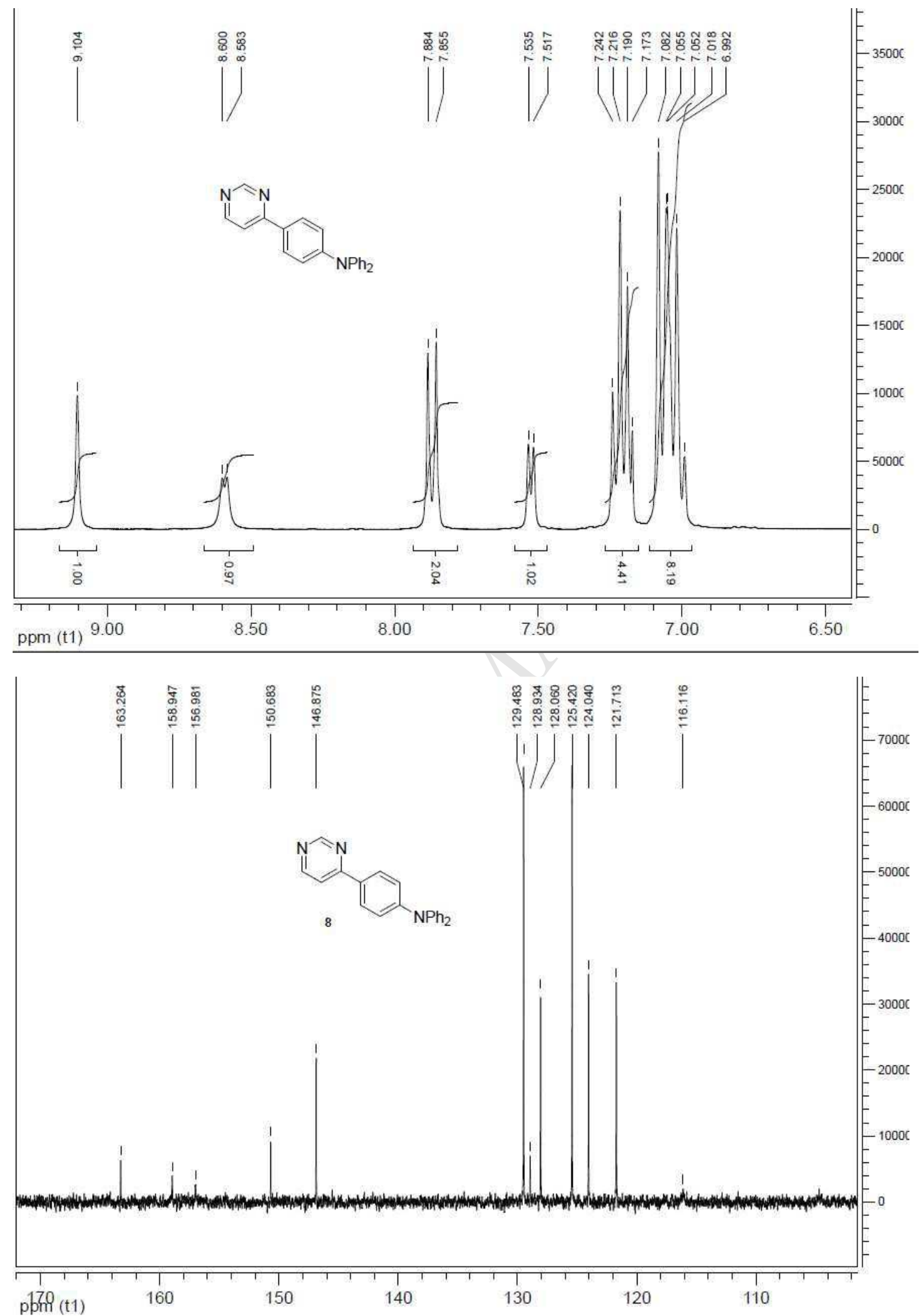



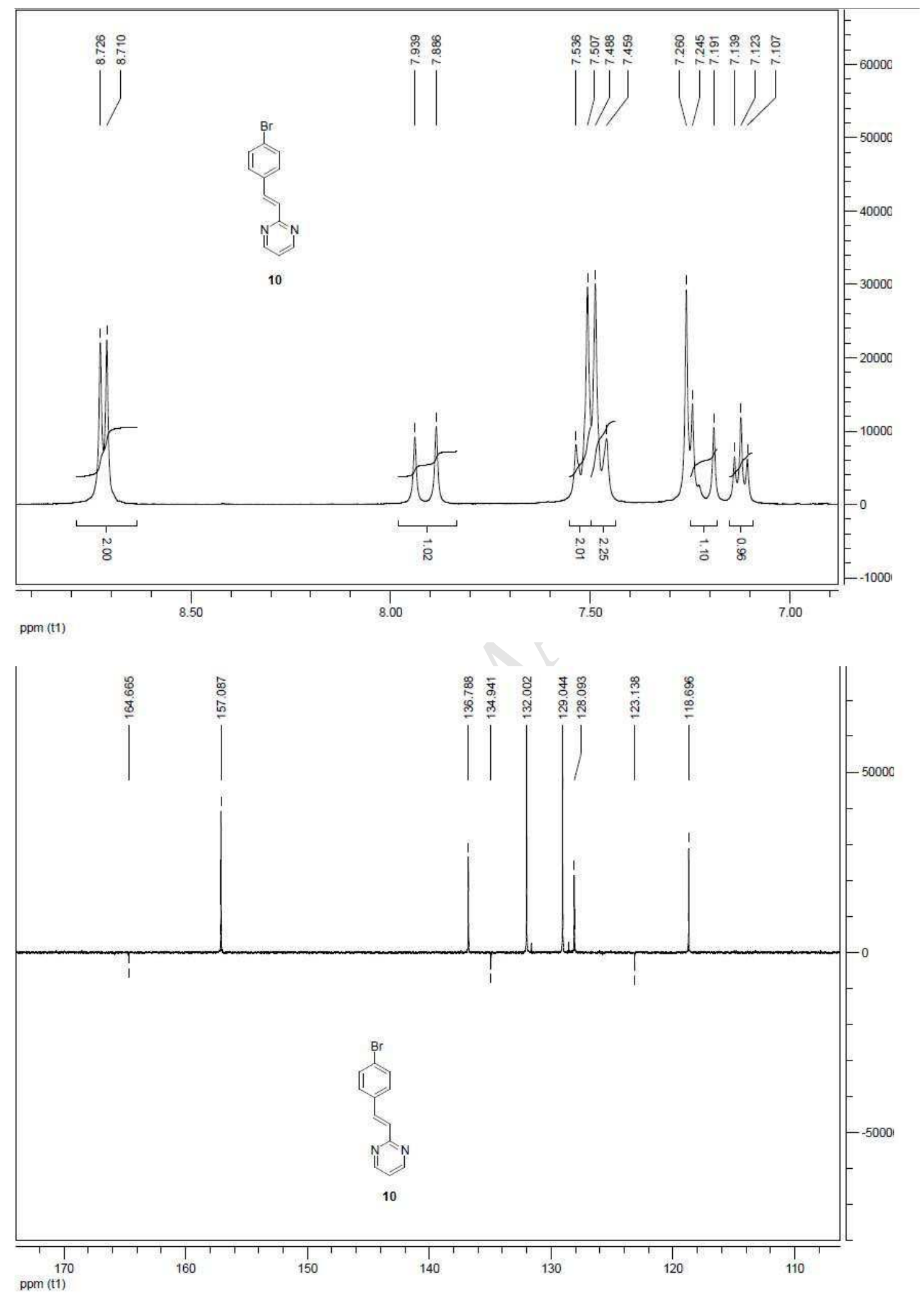

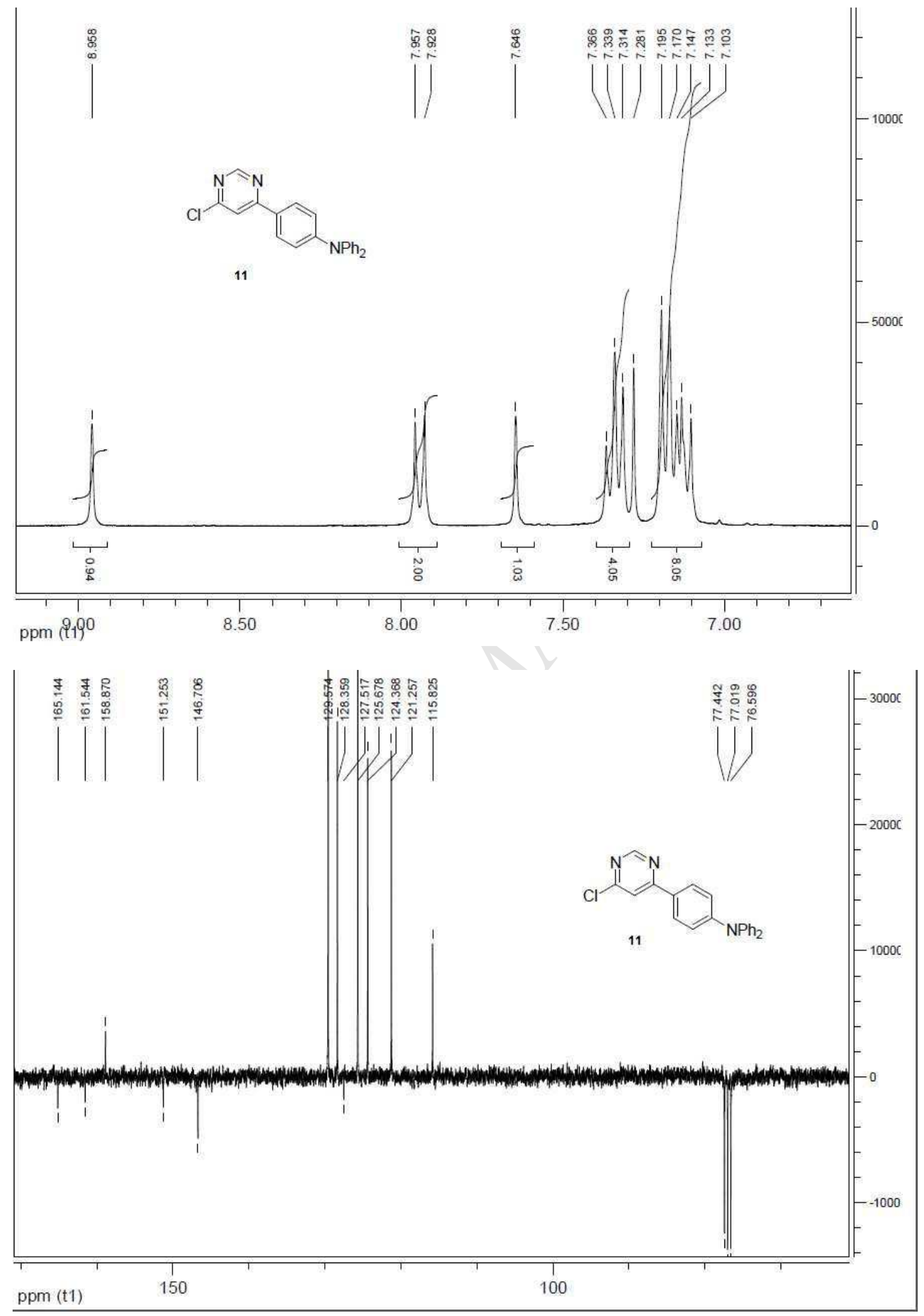


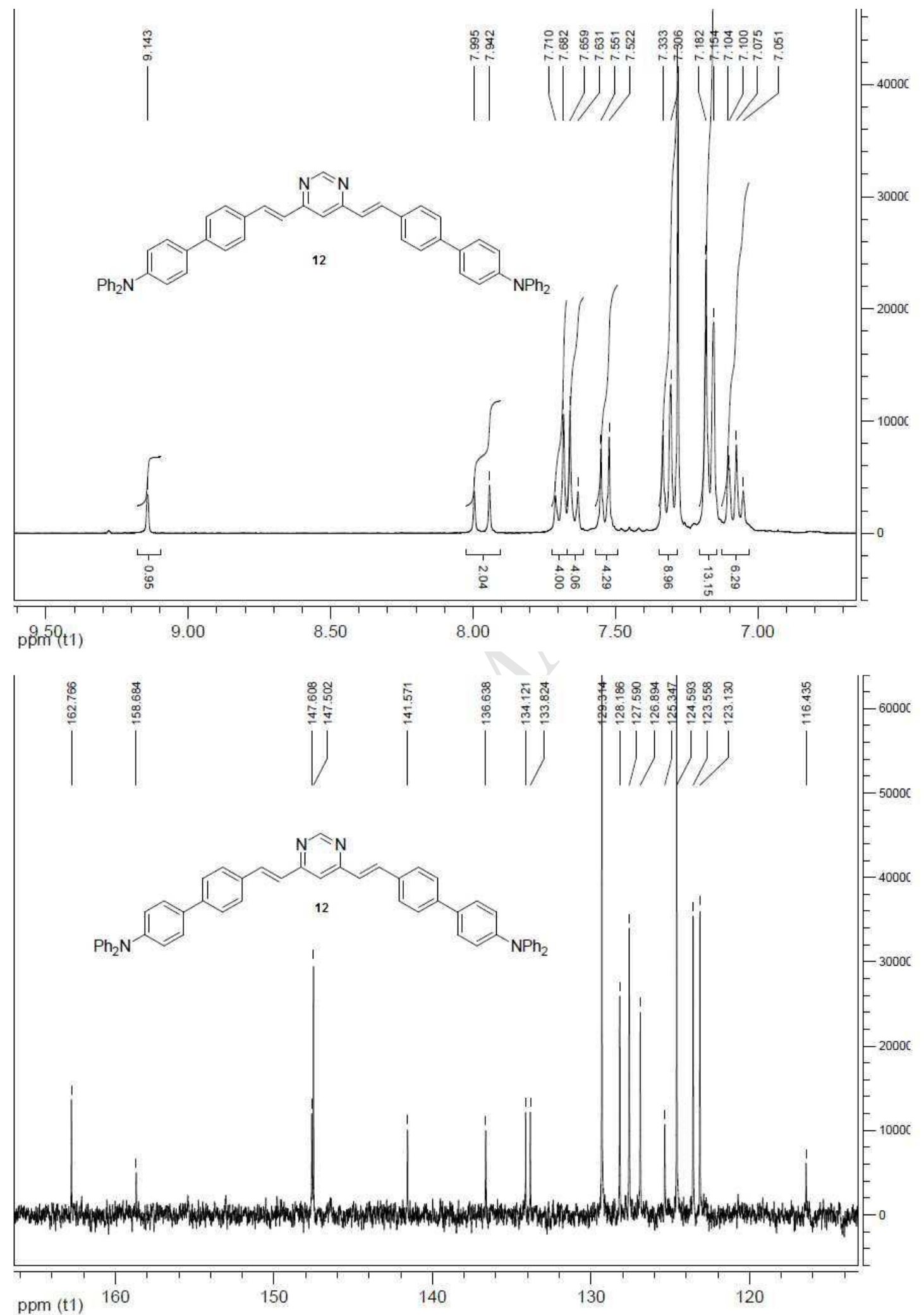


${ }^{1}$ a) Achelle S, Barsella A, Baudequin C, Caro B, Robin-le Guen F. Synthesis and photophysical investigation of a series of push-pull arylvinyldiazine chromophores. J Org Chem 2012;77:4087-96. b) Achelle S, Nouira I, Pfaffinger B, Ramondenc Y, Plé N, Rodríguez-López J. V-shaped 4,6-bis(arylvinyl)pyrimidine oligomers: synthesis and optical properties. J Org Chem 2009;74:3711-7. 